\title{
Assessment of a decentralized grid- connected photovoltaic (PV) / wind / biogas hybrid power system in northern Nigeria
}

\author{
Ismail Abubakar Jumare ${ }^{1,2^{*}}$ (D), Ramchandra Bhandari ${ }^{3}$ and Abdellatif Zerga ${ }^{2}$
}

\begin{abstract}
Electricity is considered a fundamental service which is highly correlated with sustainable development. Nigeria will serve as a case study that has been experiencing an energy deficit, and severely needs a strong adoption of alternative energy sources.

This paper provides a detailed assessment of a grid-connected photovoltaic/wind/biogas hybrid energy system in the northern part of Nigeria using a combined Hybrid Optimization Model for Electric Renewables (HOMER), Microsoft Excel, and Ganzleitliche Bilanz (GaBi) tools. They are based on techno-economic modeling and optimization as well as comparison with the same configuration in its off-grid form. Sensitivity analysis as well as an energy efficiency assessment of the proposed grid-connected system was carried out, followed by a supplementary economic benefit assessment of a system switch over and an evaluation of the impacts of life cycle emissions. A wrap-up reliability assessment based on the utility grid status quo and policy implications was also carried out. The results of the analysis for the grid-connected system showed a 3\% increase in the overall energy supply, and a $68 \%$ and $85 \%$ decrease in net present costs (NPC) and levelized costs of energy (LCOE), respectively, with avoided emissions as compared to its comparable off-grid configuration. Moreover, the energy efficiency (EE) determined for the proposed grid-connected system resulted in a massive reduction in the component sizing, energy supply, and an ultimate $88 \%$ and $81 \%$ reduction in overall NPC and LCOE, respectively. The sensitivity analysis as well as the other supplementary evaluations indicated clear impacts on the different performance measures.

(Continued on next page)
\end{abstract}

\footnotetext{
* Correspondence: shehius61@yahoo.com

${ }^{1}$ Mechanical Engineering Department, Faculty of Technology, University of Tlemcen, B.P. 119/Pôle Chetouane, 13000 Tlemcen, Algeria

${ }^{2}$ Pan African University Institute of Water and Energy Sciences - PAUWES, c/o University of Tlemcen, B.P. 119/Pôle Chetouane, 13000 Tlemcen, Algeria

Full list of author information is available at the end of the article
}

(c) The Author(s). 2020 Open Access This article is licensed under a Creative Commons Attribution 4.0 International License, which permits use, sharing, adaptation, distribution and reproduction in any medium or format, as long as you give appropriate credit to the original author(s) and the source, provide a link to the Creative Commons licence, and indicate if changes were made. The images or other third party material in this article are included in the article's Creative Commons licence, unless indicated otherwise in a credit line to the material. If material is not included in the article's Creative Commons licence and your intended use is not permitted by statutory regulation or exceeds the permitted use, you will need to obtain permission directly from the copyright holder. To view a copy of this licence, visit http://creativecommons.org/licenses/by/4.0/ The Creative Commons Public Domain Dedication waiver (http://creativecommons.org/publicdomain/zero/1.0/) applies to the data made available in this article, unless otherwise stated in a credit line to the data. 


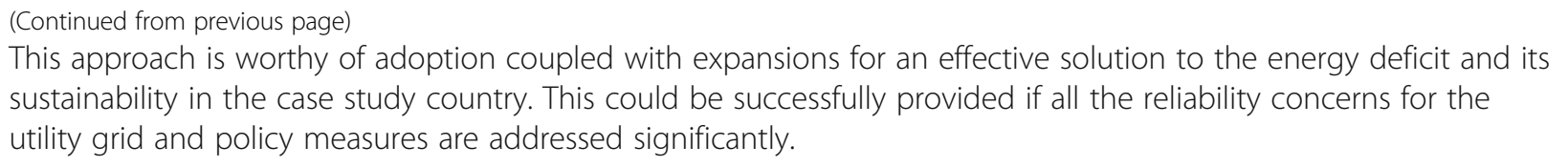

Keywords: Hybrid energy system, grid integration, energy management, sensitivity analysis, energy efficiency assessment

\section{Highlights}

- Hybrid renewable systems deserve strong consideration for grid integration on a sustainability basis.

- Energy supply increased by 3\% from the standalone to the proposed grid-connected system.

- An energy efficiency measure for the grid-connected system led to an $81 \%$ reduction in the LCOE.

- Sensitivity and other supplementary analysis showed impacts on system performance.

- Surmounting utility grid challenges and strong policy interventions are necessary.

\section{Background}

Numerous research studies conducted in the field of energy have shown the depleting nature of conventional energy sources, especially fossil fuels, coupled with direct consequences of global warming. This necessitates searching for alternatives in energy solutions. These alternative energy sources are in other words termed renewable energy sources such as solar, wind, hydro, biomass, and geothermal energy. However, the combination of two or more of these sources is sometimes necessary for giving rise to a hybrid energy system. Hence, by definition, a hybrid energy system is the combination of two or more energy conversion devices aimed at overcoming limitations associated with either or all [1]. The major limitation of renewable systems and their sources has been intermittent availability, as some resources are available in stock while some fluctuate. The hybrid system has some advantages due to an incorporation of renewable sources as described in the literature. These are fuel flexibility due to different adjustments that could be provided in combination to ensure optimum operation and efficiency of systems as well as reliability, and viability in terms of economics, energy security, improved power quality, reduced carbon emission, fossil fuels saving, and employment opportunity $[1,2]$.

In addition, a power generating system could be either decentralized (distributed) or centralized. The former involves having different sets of power generating systems for different load demands, and is the intended target for this research paper. However, the latter involves securing a single power plant to one or many load centers without the need for distribution in the system execution [3]. Centralized power generation could be relatively more challenging than the decentralized type due to its high costs of execution and more losses of operation. This is because the power has to be transported either on a national/regional utility grid or a mini/isolated grid depending on the network category.

Likewise, still on the basis of a network, the power system may be single component-based or hybrid-based and could be conventionally designed in two ways, viz. grid-connected and off-grid or standalone. The gridconnected hybrid system works in such a way that the power generated will be integrated in a grid network on either the transmission, sub-transmission, or distribution site of the network, and the load gets its power from the grid or from the system directly where excesses are forwarded to the grid and deficits require grid power sourcing. The major advantage of the grid-connected system is the fact that flexibility exists in such a way that a loss or shutdown of the system does not necessarily result in a loss of power for the load, since such losses or outages could be compensated by other alternatives in the utility grid [4]. Likewise, excess generation-when compared to electricity consumed from the grid-results in credits in line with the renewable power policy instruments and is based on countries' regulations. In contrast, off-grid-based systems are usually deployed in remote areas, i.e., areas that are far away from the existing grid where the grid extension to those locations is technically or economically impossible or challenging [4]. It has less impact as compared to a grid-connected system due to the flexibility and credits securing advantages, which are not particular to it.

Based on the above information, the design approach generally performed for any hybrid power system is stage-wise, and usually begins with an energy demand assessment, resource assessment, assessment of the barriers/constraints in terms of costs, the environmental influences, etc., and finally it has to fulfill the demands of an energy system coupled with optimization and so on. This can be addressed using different software packages, such as a Hybrid Optimization Model for Electric Renewables (HOMER), a Matrix Laboratory (MatLab/ 
Simulink), a System Advisor Model (SAM), a Transient System (TRNSYS), or a Ganzleitlichen Bilanz (GaBi) tool. They ease the modeling, optimization and control, economic analysis, life cycle assessments, and so on. Adopting two or more of these software packages becomes necessary depending on the research questions to be addressed in a power system design, as limitations may arise in handling only one.

Many studies regarding a grid-connected power system have been carried out both on the African continent and beyond. Some could be used to underline the novelty of this research paper. Pan and Dinter [5] have demonstrated the capability of a concentrating solar power (CSP) and PV hybrid system of $100 \mathrm{MW}$ nameplate capacity by addressing the need of a 100-MW base load capacity for the grid in South Africa. This analysis was performed using SAM for simulating different design configurations both individually and in combined form based upon different storage sizes for observing the energy yield, capacity factor, and economic viability. Gbalimene et al. [6] have studied the techno-economic analysis for grid integration of hybrid-based renewable energy technologies in order to satisfy the load distribution of a particular building with a peak load of about $305 \mathrm{~kW}$ in Abuja, Nigeria. The components considered were $\mathrm{PV} /$ wind without battery storage which was analyzed using HOMER. Simulation and optimization have been carried out, and different feasible configurations have been obtained. In addition, Numbi and Malinga [7] have proposed an economic analysis of a $3 \mathrm{~kW}$ residential single-phase grid interactive solar PV system in eThekwini municipality of South Africa. The approach used was the optimal control model, which is a powerful tool for solving several energy management problems. In the simulation results, variations were done for the feedin tariff (FiT) for observing the impact on energy cost savings and the payback period. An optimal gridconnected hybrid PV/wind with battery storage system sizing was performed by Nadjemi et al. [8], considering two load distributions, i.e., a residential and a dairy farm all located in Ghardaia, Algeria. The analysis has been done using a cuckoo search algorithm and has been compared with the particle-swarm sizing optimization (PSO) technique, revealing a better accuracy and less computational time compared to the PSO technique. Boussetta et al. [9] have conducted a grid-connected optimal sizing of a hybrid system for 2 load profiles (one with a $379 \mathrm{kWh} /$ day average energy consumption and the other with $113 \mathrm{kWh} /$ day) for an agricultural farm located in Morocco. In the analysis, the authors used the HOMER tool and the components considered were PV, wind, diesel generator, and battery. Madhlopa et al. [10] have studied the optimization of a PV/wind hybrid system under limited water resource conditions using meteorological data of Stellenbosch, South Africa. The plant was designed to generate $100,000 \mathrm{MWh} /$ year of energy for the grid, where the model employed was based on the water constrains of a program developed in MatLab for the economic optimization of the proposed system.

Moreover, Silinga et al. [11] conducted a study with regard to the implication of a proposed hybrid CSP peaking system (i.e., a capacity beyond the base load for the grid system) with a capacity of $3.3 \mathrm{MW}$ in South Africa. This was done through re-optimization and comparison between the fixed tariff and 2-tier tariff system, using the spatial-temporal analysis approach. Kazem and Khatib [12] have studied the techno-economic assessment of a grid-integrated photovoltaic system in Sohar, Oman. The authors have applied the MatLab tool and analyzed many parameters, such as annual yield factor, capacity factor, and costs of energy generation. Likewise, the system has been found to be very promising for the site. Optimal sizing of a hybrid grid-connected PV/wind/ biomass power system has been carried out by Gonzalez et al. [13] for the case of Central Catalonia, Spain. The life cycle cost optimization approach followed in the research has used the optimization toolbox of MatLab, coupled with a sensitivity analysis of some system cost variables and component efficiencies. The optimized configuration was concluded to be of benefit in terms of energy autonomy and environmental quality improvement. Salahi et al. [14] have completed a study regarding the design of a grid-connected hybrid system for the case of Bishesh Village, Iran, based on a peak load of $146 \mathrm{~kW}$. HOMER used different configurations and simulated them using PV, wind, and battery as well as diesel gensets and battery with both the grid connection and comparable off-grid for observing the benefits associated. Dali et al. [15] conducted an experimental study in testing and managing the performance of a hybrid $\mathrm{PV} /$ wind system. The authors have used physical emulators, battery storage, local load, dSpace controller, and a grid-tie inverter that is also capable of operating in standalone mode. The system has proved to be able to demonstrate operational capability and effectiveness at both a grid-connection mode and an autonomous mode. Lastly, Nurunnabi and Roy [16] have carried out a study on grid-connected PV/wind with battery storage in Bangladesh for an analyzed peak load of $101.32 \mathrm{~kW}$. The authors have applied the HOMER tool and compared the grid-connected configuration with its off-grid form and the benefits of such proposition were realized in terms of the system's economics.

Based on the existing work in the research area with some of them discussed in the preceding paragraph, the purpose of this paper is to indicate the technoeconomic and emission impacts of integrating a 
photovoltaics/wind/biogas hybrid system to the grid for the site of Zaria in northern Nigeria. It is further mentioned that the novelty of this research work has been seen in aspects with regard to the demand side energy efficiency assessment, the economic benefits assessment of the energy transitioning adopted with Microsoft Excel, including the $\mathrm{GaBi}$ tool life cycle emissions analysis of the systems' transitioning, as well as the reliability arguments brought forth with respect to the utility grid case and the policy implications as a qualitative measure in the case study country. However, the basis behind choosing the solar PV, wind power, and the biomass-biogas power system components are found firstly in the solar and wind resource potentials of the country being more concentrated in the northern part where the study was conducted, and secondly found in the general availability of wastes that could be turned into useful energy with the aim of ensuring waste minimization for environmental saving. Likewise, the need to integrate renewable energy into the energy system operation and to diversify the energy sources with the ultimate goal of improving energy supply and quality of lives in the case study country is of great concern. Table 1 below presents a clear comparison of the reviewed grid-connected studies with the study of this paper for a clear visibility of the contribution and novelty in ascertaining the gap filled in line of the research domain.

Following the introduction, the paper has been structured in different sections, namely the study site description and energy resource assessment, the site's load demand evaluation, the different components of the power system models with wrap-up economic models applied, the adopted research methods, the detailed and explicit results and the discussion in line with the methods specified, and lastly the conclusion section.

Selected site description and energy resource assessment Firstly, Nigerian's electricity situation has really been critical based on the electricity consumption analyzed as 129.04 kWh/Cap./year during 2016 [17, 18]. This is equivalent to a consumption of $0.35 \mathrm{kWh} / \mathrm{Cap} . /$ day and being tagged with a low electrification rate. This has been the major motivation towards the choice of the country as a joint intervention using the endowed renewable energy resources. However, in a more specific case of the study, the selected site is Zaria (coordinates $11.085^{\circ} \mathrm{N}, 7.72^{\circ} \mathrm{E}$ ), which is a local government and major city in Kaduna State of northern Nigeria. This has been further driven by the fact that despite the whole country suffering with a high energy deficit, some regions tend to be in a more critical situation than others. From experience, this selected site is faced with frequent power cuts and most households rely on gasoline or diesel generator sets to address their power shortages. The negative impacts of the generator sets are numerous, e.g., air and noise pollution resulting in health hazards and environmental degradation due to oil spillage on land and water and excessive greenhouse gas emissions.

The site of a further description is situated on a plateau at an elevation of $670 \mathrm{~m}$ above sea level [19] and has a total area of $563 \mathrm{~km}^{2}$ and a population of about 975 , 200 in 2015 [20]. Furthermore, Zaria's climate is tropical wet and dry caused by movement of inter-tropical discontinuity under two air mass influences, i.e., tropically continental and tropically maritime [21]. The wet season (summer) lasts from April to October, whereas the dry season (winter) lasts from November to March. Figure 1 gives the country and study site description on a map.

Renewable resource information about the site is crucial for the system analysis. Solar irradiance with the accompanied temperature and wind speed are the fundamental climate data considered. They are presented in Figs. 2 and 3:

Furthermore, after switching to a biomass resource as very substantial to the power system, the breakdown of the different kinds of feedstock production for the country as well as the analyzed average production for the site is provided in Table 2.

Density of clean biogas at standard temperature and pressure (stp) ranges from 1.1 to $1.5 \mathrm{~kg} / \mathrm{m}^{3}$ [29], where $1.2 \mathrm{~kg} / \mathrm{m}^{3}$ was applied in the additional evaluations of the Table 2 in view of the modeling data for biomass

\section{Load demand evaluations for the site}

The aim of the hybrid power system design is to address the energy situation of the specified site by supplying grid-connected decentralized power to the population based upon given numbers of households with a load demand specification. Within the limit of this design, about 200 households were considered in the site with an average of six persons per household for the power system sizing. This is equivalent to supplying energy to 1200 persons in the site. The breakdown of the load demand is based on the list of appliances utilized at the household level on a daily basis and time of use. The appliances specified are a reflection of a careful monitoring of the site regarding life style. It is also noted that households' energy consumption and the likes are seasonally dependent as consumption in summer (wet season) differs from that of winter (dry season). Hence, a more realistic design approach requires taking that into account. Therefore, the load demand is specified for both the summer and winter for the sizing of the energy system components. Table 3 gives the details of the load calculation and Fig. 4 summarizes the load profile for the site based on the analyzed two seasons. Further random variability has also been considered as a safety 
Table 1 Comparison of the grid-connected renewable energy system studies reviewed in this paper

\begin{tabular}{llll}
\hline Author(s) & Study location & Published year & Main content (research approach/tools and observations) \\
\hline Pan and Dinter [5] & South Africa & 2017 & $\begin{array}{l}\text { CSP and PV capability demonstration with the aid of a System Advisor Model (SAM). } \\
\text { Different configurations with different storage sizes were modeled and the } \\
\text { performances were monitored. Combined PV/CSP was seen to be more appropriate } \\
\text { and can substitute the conventional coal-fired power plant with many benefits } \\
\text { associated. }\end{array}$
\end{tabular}

Gbalimene et al. [6] Abuja, Nigeria $\quad 2016$

Numbi and Malinga [7] eThekwini,

South Africa

Nadjemi et al. [8]

Boussetta et al. [9]

Morocco

Madhlopa et al. [10] Stellenbosch,

South Africa

Silinga et al. [11] South Africa

Kazem and Khatib [12] Sohar, Oman

Gonzalez et al. [13]

Central Catalonia,

2015

Spain

Salahi et al. [14]

Dali et al. [15]

N/A

Nurunnabi and

Roy [16]

Bangladesh

2015

The study in this

paper

Authors

Study location

Jumare et al.
Zaria, Nigeria
Techno-economic evaluations of PV/wind hybrid systems using the HOMER tool. Grid-only power has been observed to be more economical as the hybrid system with the highest renewable fraction considered more appropriate owing to the advantages it offers.

Economic analysis of PV system integration for the grid using an optimal control model. Strong policies were linked with sensitivity evaluations regarding the Feed-in Tariff. The authors have observed that the higher the grid energy cost savings, the lower the system payback period and also the lower the need for battery bank storage will be (when neglecting the effect of a grid failure).

Optimal sizing of a grid-connected hybrid PV/wind/battery system using a cuckoo search algorithm (CSA). Comparison has been done with the particle-swarm sizing optimization (PSO) technique. The authors observed a better accuracy and less computational time for the case of the CSA.

Grid-connected optimal sizing of a hybrid PV/wind/diesel system with battery storage coupled with sensitivity analysis using the HOMER tool. A particular hybrid configuration in the optimization was considered as more feasible.

Optimization of grid-connected PV/wind system under limited water resource conditions using a MatLab program with adequate sensitivity measures (water-energy nexus concern). The authors have observed that the PV technology requires more water than wind technology in the system execution.

Spatial-temporal analysis (STA) applied for the implication of the proposed hybrid CSP peaking system. Optimization and comparison between fixed tariff and 2-tier tariff system was performed. The authors observed the CSP peaking system to be feasible using the 2-tier system based on a part load operation with storage (policy-linkage concern).

2013 Techno-economic assessment of a grid-integrated photovoltaic system using MatLab. Different technical and economic parameters have been analyzed and the system has proved to be promising at the site.

Optimal sizing of a hybrid grid-connected PV/wind/biomass power system. A life cycle costing optimization approach using MatLab was employed with adequate techno-economic sensitivity. The optimized configuration has been concluded to be of tremendous benefits regarding economic and environmental concerns.

Optimal design of a grid-connected system using PV/wind/battery and a diesel/ battery system with comparison to off-grid configurations using the HOMER tool. The benefits of the transition have been clearly observed.

Experimental study regarding managing the hybrid PV/wind system with the aid of emulators, space controller, complex inverter using a double operation mode, and so on. Operational capability and effectiveness have been confirmed for both the grid-connected mode and the standalone mode.

A grid-connected hybrid PV/wind/battery system design with the aid of a HOMER tool has been used. Comparative analysis has been done with same configuration as in the off-grid system. The overall benefits have been observed in terms of economics and so on.

Published year Main content (research approach and tools applied)
Detailed system modeling, optimization, and demand side energy efficiency assessment has been carried out. An assessment of the economic benefits of energy system transitioning, including the impact of life cycle emissions on energy transitioning, as well as reliability arguments have brought forth with respect to the utility grid case and the overall policy implications. The tools employed have been the HOMER, Microsoft Excel, and GaBi. 

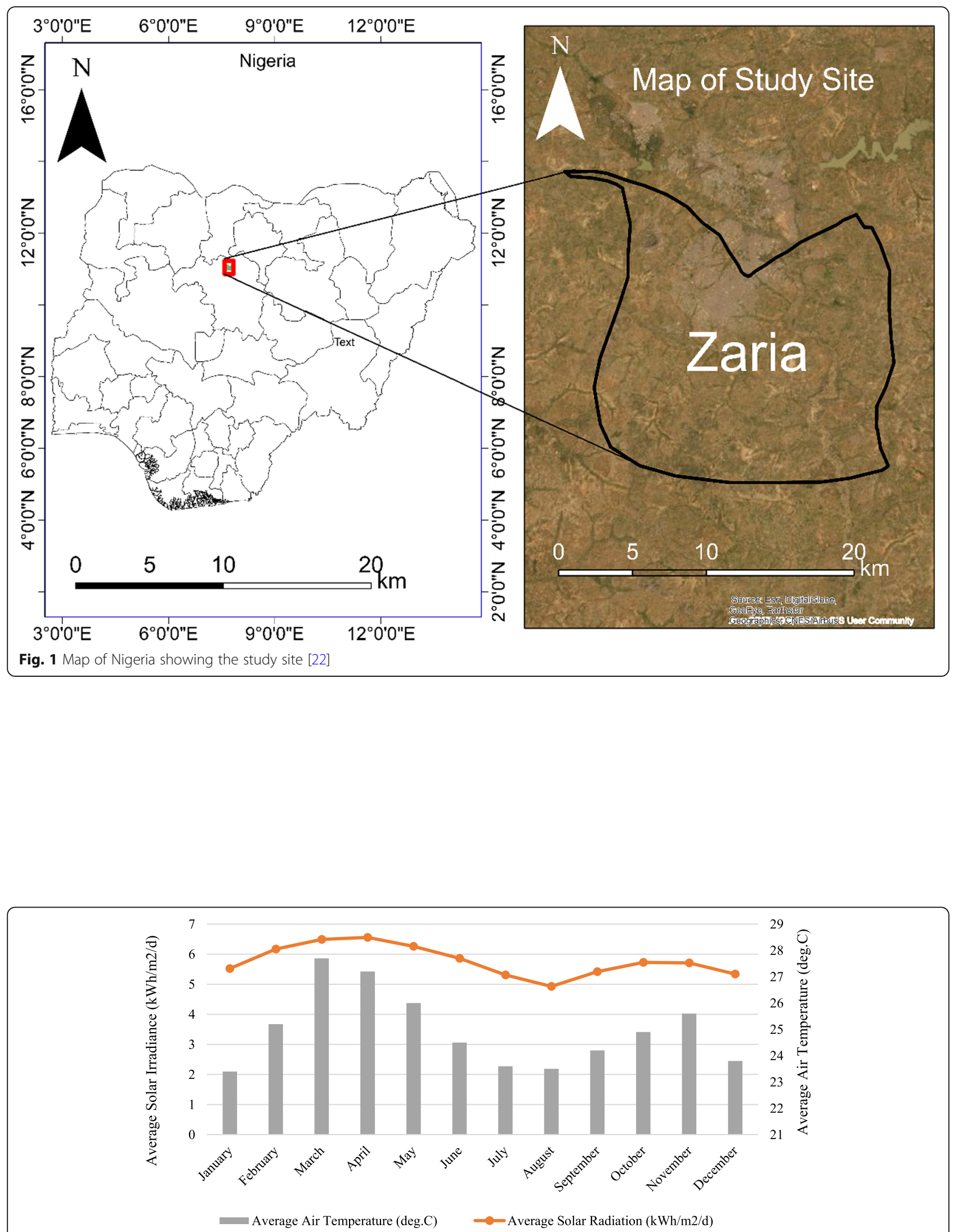

Fig. 2 Average monthly solar irradiation and air temperature for the site [23] 


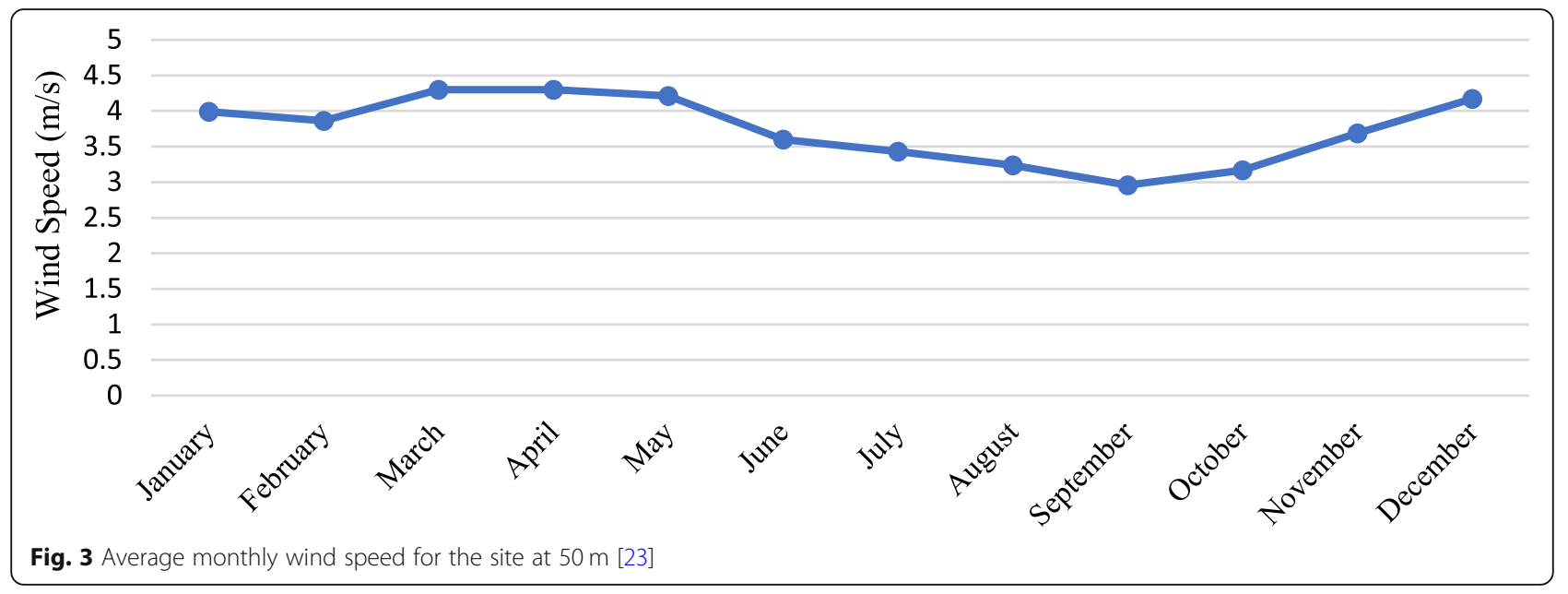

factor for a more realistic design as presented in Table 4 which depicts how the summary of the analyzed load specification has been scaled.

\section{The Power system component models and economic parameters \\ Solar PV system models}

Models for solar PV systems are quite numerous. A report of the solar PV power output models based on different input parameters has been obtained from Adaramola et al. and Adaramola et al. [30, 31] as follows:

$$
P_{p \nu}=Y_{p v} f_{p v}\left(\frac{G_{T}}{G_{T, S T C}}\right)\left[1+\alpha_{p}\left(T_{C}-T_{C, S T C}\right)\right]
$$

where $P_{p v}=$ solar PV output power $(\mathrm{kW}), Y_{p v}=$ rated capacity of the PV array, i.e., its power output under $\operatorname{STC}(\mathrm{kW}), f_{p v}=$ PV derating factor $(\%), G_{T}=$ solar radiation incident on PV array $\left(\mathrm{kW} / \mathrm{m}^{2}\right), G_{\mathrm{T}}$, STC $=$ incident solar radiation under standard test conditions $(1 \mathrm{~kW} /$ $\left.\mathrm{m}^{2}\right), \alpha_{p}=$ temperature coefficient of power $\left(\% /{ }^{\circ} \mathrm{C}\right), T_{C}=$ PV cell temperature $\left({ }^{\circ} \mathrm{C}\right)$, and $T_{C}, \quad S T C=\mathrm{PV}$ cell temperature @ standard test condition $\left(25^{\circ} \mathrm{C}\right)$.
On neglecting the effect of temperature, the power model becomes less complicated as follows:

$$
P_{p v}=Y_{p v} f_{p v}\left(\frac{G_{T}}{G_{T, S T C}}\right)
$$

With regard to the energy generation bit of the PV system, Kusakana and Vermark [32] have reported on a model for predicting such, based on multiple parameters in line with the preceded PV power determination as follows:

$$
E_{P V}=A \times \eta_{m} \times P_{f} \times \eta_{P C} \times I
$$

where $E_{P V}=$ total electrical energy output, $A=$ total area of the photovoltaic generator $\left(\mathrm{m}^{2}\right), \eta_{m}=$ module efficiency (\%), $\eta_{P C}=$ power conditioning efficiency (\%), $I=$ hourly irradiance $\left(\mathrm{kWh} / \mathrm{m}^{2}\right), P_{f}=$ parking factor.

\section{Wind turbine system models}

Many mathematical models also exist in predicting the performance of a wind turbine system. According to Madhlopa et al. and Taher et al. [10,33], the models are based on different conditions for

Table 2 Animal waste production: the country and the analyzed site values in 2014 [24-28]

\begin{tabular}{llllllll}
\hline Item & $\begin{array}{l}\text { National production } \\
\text { (million heads) }\end{array}$ & $\begin{array}{l}\text { Site production } \\
\text { on average } \\
\text { (thousand heads) }\end{array}$ & $\begin{array}{l}\text { Dry matter } \\
\text { production } \\
(\mathrm{kg} / \mathrm{head} / \text { day) }\end{array}$ & $\begin{array}{l}\text { National dry } \\
\text { matter production } \\
(\mathrm{kg} / \mathrm{year})\end{array}$ & $\begin{array}{l}\text { Sites dry matter } \\
\text { production on } \\
\text { average }(\mathrm{kg} / \text { year) }\end{array}$ & $\begin{array}{l}\text { Carbon } \\
\text { content on } \\
\text { average }\end{array}$ & $\begin{array}{l}\text { Biogas potential } \\
\left(\mathrm{m}^{3} / \mathrm{kg} \text { and } \mathrm{kg} / \mathrm{kg}\right. \\
\text { of dry matter) }\end{array}$ \\
\hline Cattle & 19.54 & 22.97 & 2.860 & $2.04 \times 10^{10}$ & $2.40 \times 10^{7}$ & $22.5 \%$ & 0.20 and 0.24 \\
Goat & 72.47 & 85.16 & 0.552 & $1.46 \times 10^{10}$ & $1.72 \times 10^{7}$ & $29.5 \%$ & 0.25 and 0.30 \\
Pig & 7.07 & 8.30 & 0.661 & $1.71 \times 10^{9}$ & $2.00 \times 10^{6}$ & $40.7 \%$ & 0.56 and 0.67 \\
Sheep & 41.33 & 48.56 & 0.329 & $4.96 \times 10^{9}$ & $5.83 \times 10^{6}$ & $31.4 \%$ & 0.25 and 0.30 \\
Chicken & 144.95 & 170.33 & 0.043 & $2.28 \times 10^{9}$ & $2.67 \times 10^{6}$ & $32.6 \%$ & 0.28 and 0.34 \\
Horse & 0.11 & 0.13 & 3.3 & $1.30 \times 10^{8}$ & $1.54 \times 10^{5}$ & $41.5 \%$ & 0.30 and 0.36 \\
Total & 285.46 & 335.45 & $\mathrm{~N} / \mathrm{A}$ & $2.04 \times 10^{10}$ & $5.22 \times 10^{7}$ & $\mathrm{~N} / \mathrm{A}$ & $\mathrm{N} / \mathrm{A}$ \\
\hline
\end{tabular}




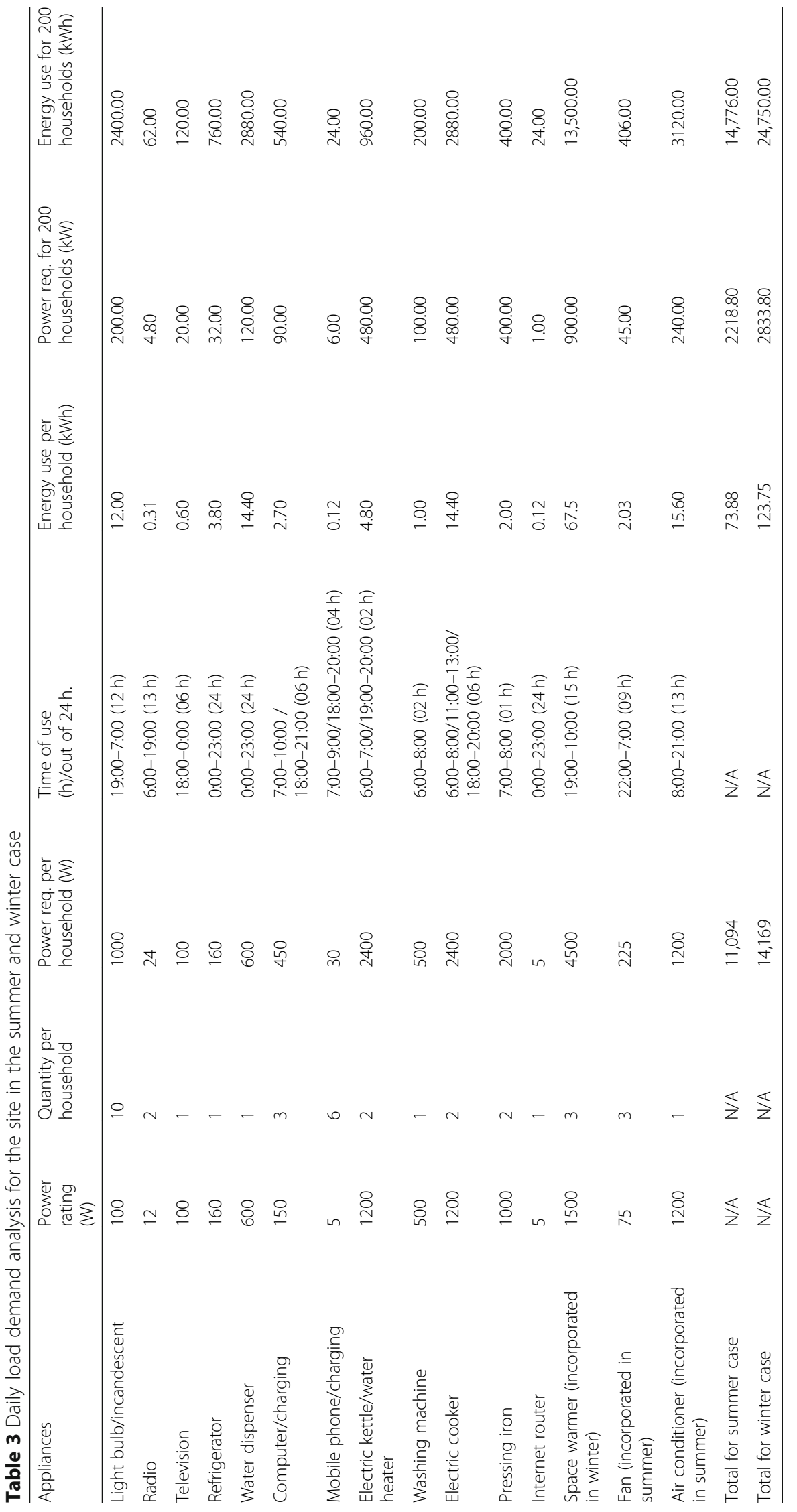




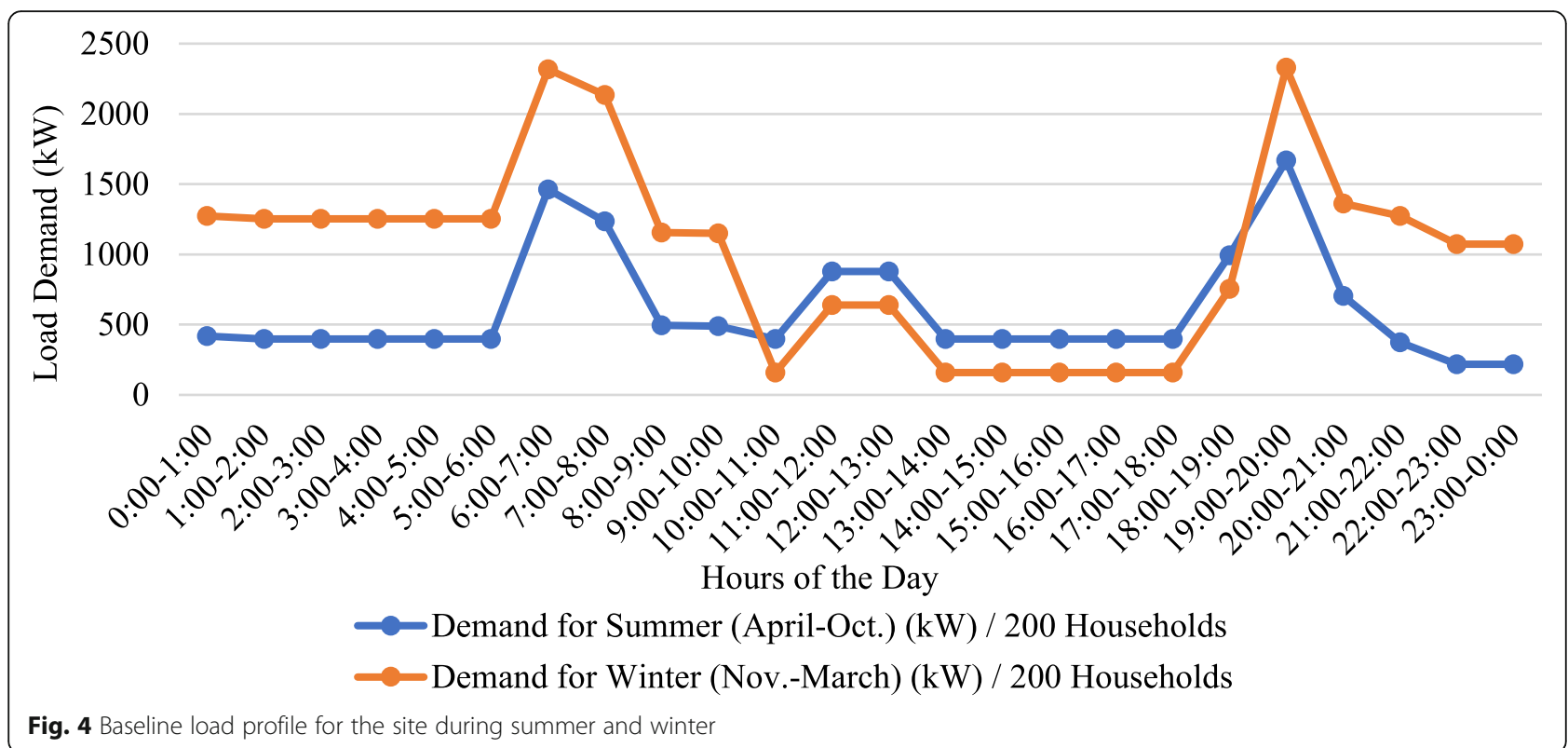

estimating the power output of a typical wind turbine are as follows:

$$
P_{W T}=\left\{\begin{array}{cc}
a V^{3}-b P_{r t} & V_{c i}<V \leq V_{r t} \\
P_{r t} & V_{r t}<V<V_{c o} \\
0 & V>V_{c o}
\end{array}\right.
$$

such that $a=\frac{P_{r t}}{V_{r t}^{3}-V_{c i}^{3}}$ and $b=\frac{V_{c i}^{3}}{V_{r t}^{3}-V_{c i}^{3}}$

where $P_{W T}=$ wind turbine output power, $P_{r t}=$ rated power of the wind turbine, $V_{r t}=$ rated wind speed, $V_{c i}=$ cut-in wind speed, $V_{c o}=$ cut-out wind speed

Also,

$$
P_{W T}=1 /{ }_{2} \rho A V^{3} C_{p}
$$

where $\rho=$ density of air $=1.225 \mathrm{~kg} / \mathrm{m}^{3}, A=$ wind turbine area $=\pi \mathrm{r}^{2}\left(\mathrm{~m}^{2}\right)$, where $r=$ rotor radius $(\mathrm{m}), V$ $=$ wind velocity $(\mathrm{m} / \mathrm{s}), C_{p}=$ coefficient of power $=$ Max. value is 0.59
Finally, a model for predicting the energy output of a wind turbine has been reported by Kusakana and Vermark [32] in terms of almost similar parameters to that of the power output. It is therefore presented below:

$$
\begin{aligned}
E_{W T}= & \underset{1 / 2}{1 / 2} \times \rho \times V^{3} \times C_{p w} \times \eta_{W T} \\
& \times t
\end{aligned}
$$

where $E_{W T}=$ energy output of the wind turbine, $C_{p w}=$ wind turbine performance coefficient, $\eta_{W T}=$ combined efficiency of wind turbine (\%), $t=$ time.

\section{Biomass genset system models}

The mathematical models for predicting the performance of the fuel ignition genset are also available. According to Adaramola et al. and Adaramola et al. [30, 31], some models for predicting the fuel consumption, total life, and efficiency of the genset system have been obtained and are presented below:

Table 4 Supplementary load demand specifications for scaling

\begin{tabular}{lll}
\hline Random variability assumption: day to day $=15 \%$, time step to time step $=20 \%$ & $\begin{array}{l}\text { Saseline data } \\
\text { (before random } \\
\text { variability) }\end{array}$ \\
Parameter & 18,529 & 18,529 \\
Average energy demand $(\mathrm{kWh} /$ day) & 772 & 772 \\
Average power demand $(\mathrm{kW})$ & 2329 & 4059 \\
Peak power demand $(\mathrm{kW})$ & 0.33 & 0.19 \\
Load factor & & 772 \\
\hline
\end{tabular}




$$
F_{c}=a P_{\text {rated }}+b P_{\text {gen }}
$$

where $F_{c}=$ fuel consumption $(\mathrm{L} / \mathrm{h}), P_{\text {rated }}=$ rated power capacity of the generator $(\mathrm{kW}), P_{\text {gen }}=$ generator power output (kW), $a=$ generator's fuel curve intercept coefficient $\left(\mathrm{L} / \mathrm{h} / \mathrm{kW}_{\text {rated }}\right)$, and $b=$ generator's fuel curve slope (L/h/kW output).

Also,

$$
R_{\text {gen }}=\frac{Q_{\text {running }- \text { time }}}{Q_{\text {year }}}
$$

where $R_{\text {gen }}=$ generators operational life (year), $Q_{\text {running }}$ - time $=$ total running hours for the generator $(\mathrm{h}), Q_{\text {year }}=$ actual annual operating hours (h/year)

$$
\eta_{\text {gen }}=\frac{3.6 P_{\text {gen }}}{\dot{\mathrm{m}}_{\text {fuel }} L H V_{\text {fuel }}}
$$

such that $\dot{m}_{f u e l}=\rho_{\text {fuel }}\left(\frac{F_{c}}{1000}\right)$

where $\eta_{\text {gen }}=$ generator's efficiency, $\dot{m}_{\text {fuel }}=$ mass flow rate of the fuel $(\mathrm{kg} / \mathrm{h}), \rho_{\text {fuel }}=$ density of the fuel $\left(\mathrm{kg} / \mathrm{m}^{3}\right)$, $L H V_{\text {fuel }}=$ latent heat of vaporization of the fuel.

Finally, Kusakana and Vermark [32] put forward a model suitable for determining the total electrical energy generation from a fuel ignition generator as follows:

$$
\begin{aligned}
& \text { Electrical Energy Output }\left(E_{G}\right) \\
& \quad=P_{\text {rated }} \times \eta_{\text {gen }} \times t
\end{aligned}
$$

\section{System economic parameters with their models}

1) Discount rates (real and nominal): these are interesting rates that are considered in a cash flow analysis, of which the real one takes inflation rate into account, where the nominal one neglects the effect of inflation. The following formula relates the 2 discount rates as put forward by Nurunnabi and Roy [16].

$$
i=\frac{i^{\prime}-F}{1+F}
$$

where $i=$ real discount rate, $i^{\prime}=$ nominal discount rate, and $F=$ annual inflation rate.

2) Net present costs (NPC): this is defined as the aggregate of the capital costs and the discounted future costs incurred by the system over the entire life of the project. The model for evaluating such economic parameter has been provided in Eq. 12. In line with the NPC is the operating cost, where its formula is given in Eq. 13.

$$
N P C=C+\sum_{n=1}^{N} \frac{\mathrm{O} \& \mathrm{M}}{(1+i)^{n}}
$$

where $C=$ capital $/$ investment costs $(\$), \mathrm{O} \& \mathrm{M}=$ operation and maintenance costs, $i=$ discount rate/real discount rate, and $N=$ project life time.

$$
\text { Operating cost }=\operatorname{CRF}\left(i, N_{\text {Project }}\right) \cdot \operatorname{NPC}-\operatorname{CRF}\left(i, N_{\text {Project }}\right) \cdot C
$$

where $\mathrm{CRF}=$ capital recovery factor.

3) Capital recovery factor (CRF): this critical parameter is relevant in calculating the value or cost of an annuity. It is represented by the below formula that was reported by Adaramola et al. [31].

$$
\mathrm{CRF}=\frac{i \times(1+i)^{N}}{(1+i)^{N}-1}
$$

4) Levelized costs of energy (LCOE): this could be defined as the total costs to generate a unit of energy for a system over its entire life. It could also be seen as the amount at which the energy must be sold to have a break-even. It is given by the below formula reported by the Fraunhofer Institute for Solar Energy [34] as applied.

$$
\mathrm{LCOE}=\frac{I+\sum_{t=1}^{n} \frac{A_{t}}{(1+i)^{n}}}{\sum_{t=1}^{n} \frac{M e l}{(1+i)^{n}}}
$$

where $I=$ capital costs/investment costs $(\$), A_{t}=$ annual total costs/operation and maintenance costs, and $\mathrm{Mel}=$ annual energy/electricity generated (kWh). 


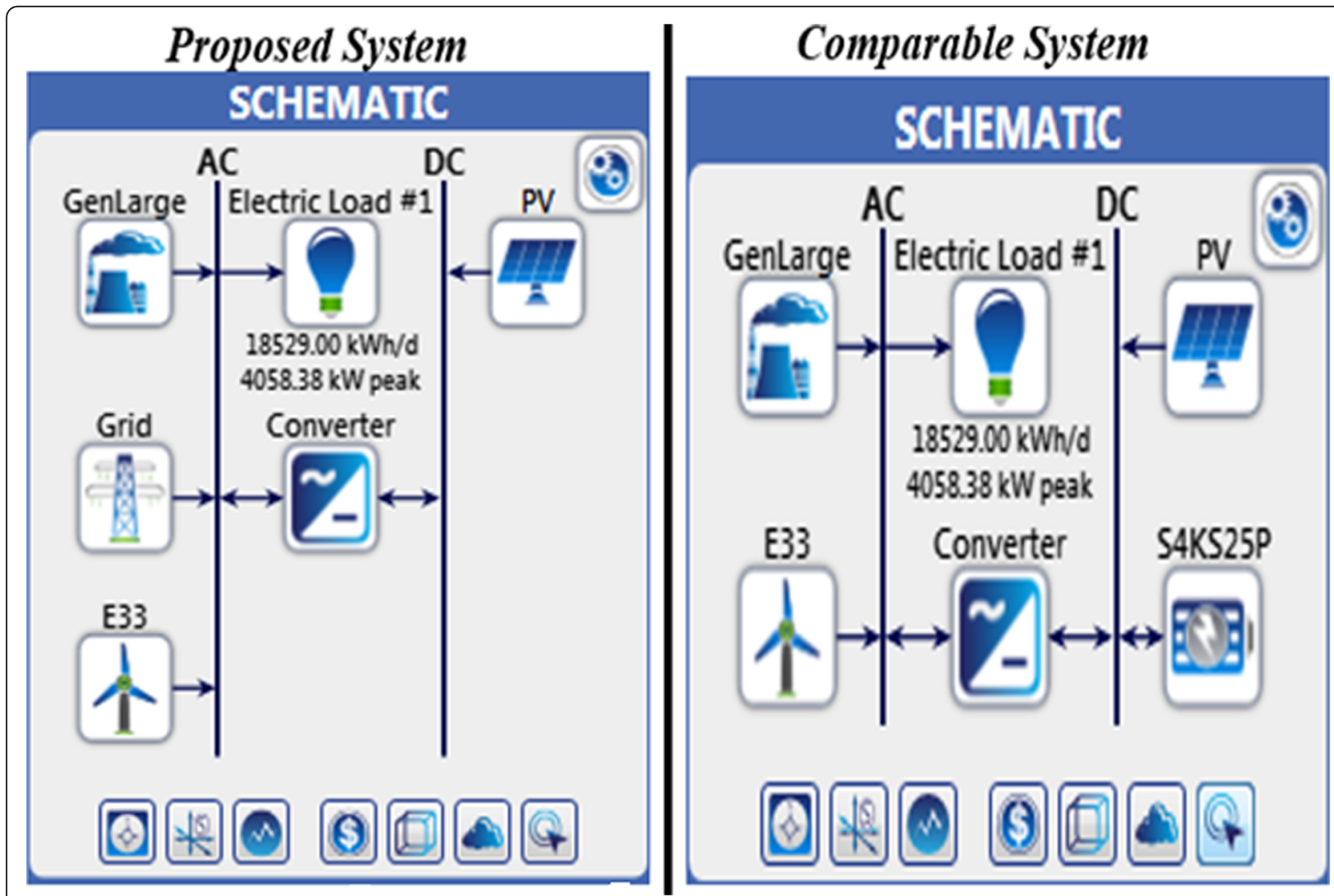

Fig. 5 Screenshot of a HOMER block diagram for the systems architecture

\section{Methods}

The assessment approach adopted was a grid-connected solar PV/wind-turbine/biomass gasified power system without storage. The reason behind neglecting the storage system was due to the incorporation of a utility grid as a backup system. Hence, generations in excess of demand necessitates forward the excess energy to the grid. In short, the generation of the demand results is based upon the compensation of grid power to meet up with the demand. This configuration was then compared to its off-grid-based configuration where battery storage was incorporated as the backup system in order to clearly see the gap between the two scenarios for better decision-making. The systems' architecture is described in Fig. 5.

From the systems' architecture figure, an obvious transition in power transmission to the demand side, utility grid, and battery storage is evident depending on the kind of power requirement based upon the established DC and AC supply buses. This is being taken into account by using a bi-directional inverter that works as both an inverter and a rectifier, depending on the power to be dispatched in operation. The inverter specification is given in the Appendix section in Table 14. In all cases, the "HOMER software" was used for the sizing, simulation, and optimization in obtaining the technically optimal parameters with the corresponding optimum configuration based on least $\mathrm{NPC}$, and in line with all the analyzed design input parameters presented in the Appendix section. This included the utility grid input specification of Table 13 , the input specification for the power system components of Table 14, and additional input specification for the biogas genset of Table 15. Further economic analysis regarding operating costs and LCOE determination for each system case were conducted using Microsoft Excel.

The general description of how the HOMER software works in the system design based on the load specification of the components' modeling, optimization, and so on was clearly demonstrated in the model given in Fig. 6.

The operational principle in the energy management for the proposed grid-connected system is comprised of three stages. The first stage relates to the solar PV and wind turbine components focused on fulfilling the demand, and the third component representing the biogas genset is optimized in order to be 


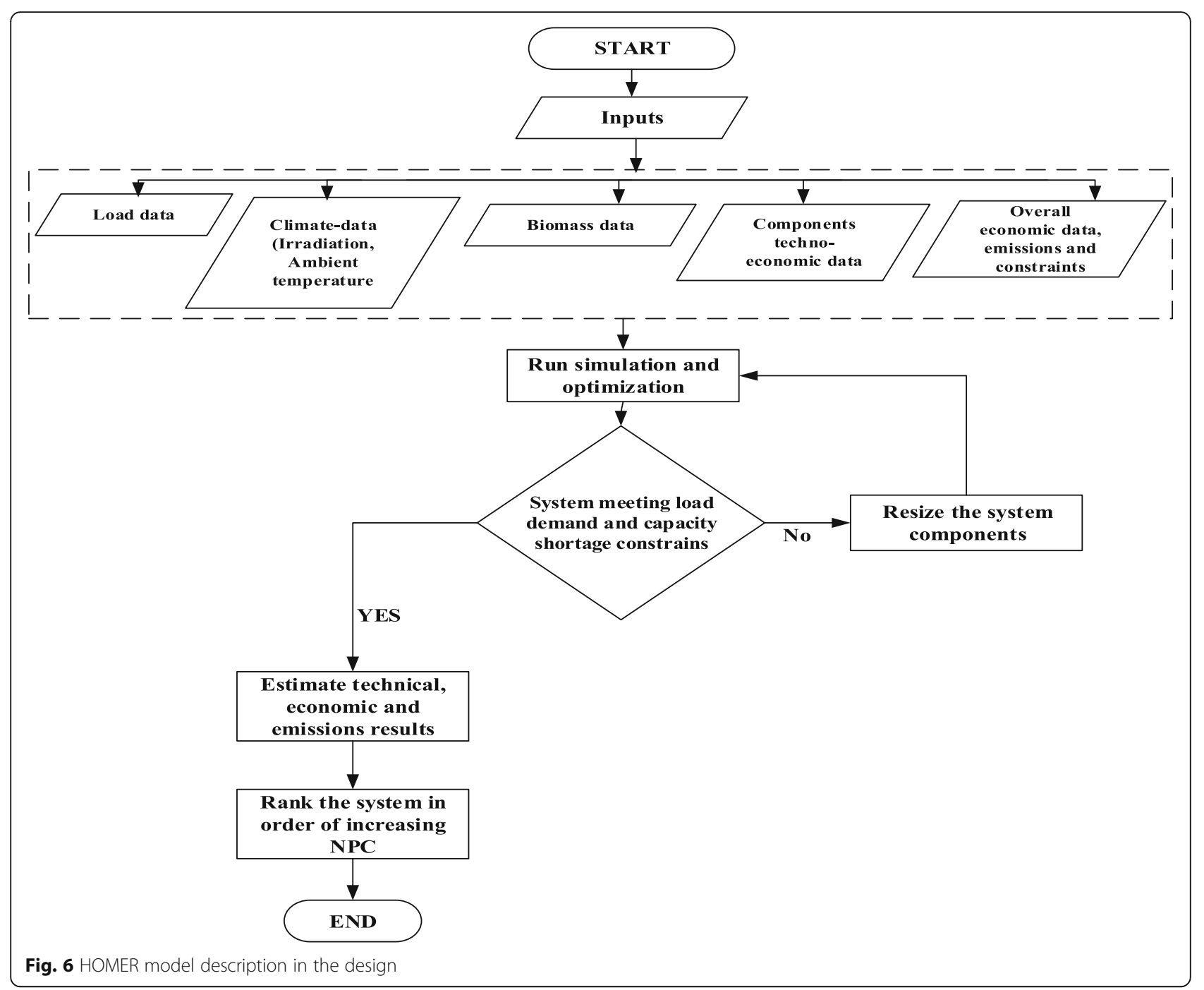

automatically activated based on its minimum load ratio on occasions of insufficiency of solar PV and wind turbine components. The second stage relates to the grid intervention on occasions of total power deficit of the whole system in comparison to the load demand. Hence, the utility grid power is being sourced/purchased to meet the demand based on a defined limit. The third stage also relates to the grid intervention on occasions of total power of the system in excess of the load demand, where the surplus is sent/sold to the utility grid based on the defined limit. The management strategy is clearly described in the model presented in Fig. 7.

Sensitivity analysis was performed to investigate the grid-connected system based on some technical and economic parameters. The technical parameters were solely the climate-based resource data viz. the scaled annual average wind resource, the scaled annual average solar resource, with the accompanied scaled annual average ambient temperature, where an assumption of $5 \%$ decrease and $5 \%$ increase was provided to the original data. This is in view of possible fluctuations due to the high uncertainty of the climate data. The economic parameter considered was the discount rate being a strong determinant for the time value of money in the cash flow evaluations. The assumption to the baseline discount rate considered was a decrease and an increase of $1 \%$ and $2 \%$, respectively, in the sensitivity.

Likewise, an energy efficiency assessment was offered for the proposed optimized grid-connected configuration with further simulation and re-optimization using the "HOMER tool" for observing their impact. The focus was on the adjustment of the load demand by switching of appliances specifically for lighting and heating requirements. For the lighting aspect, switching was done from the already specified use of incandescent bulbs in the load calculations to the use of a "light 


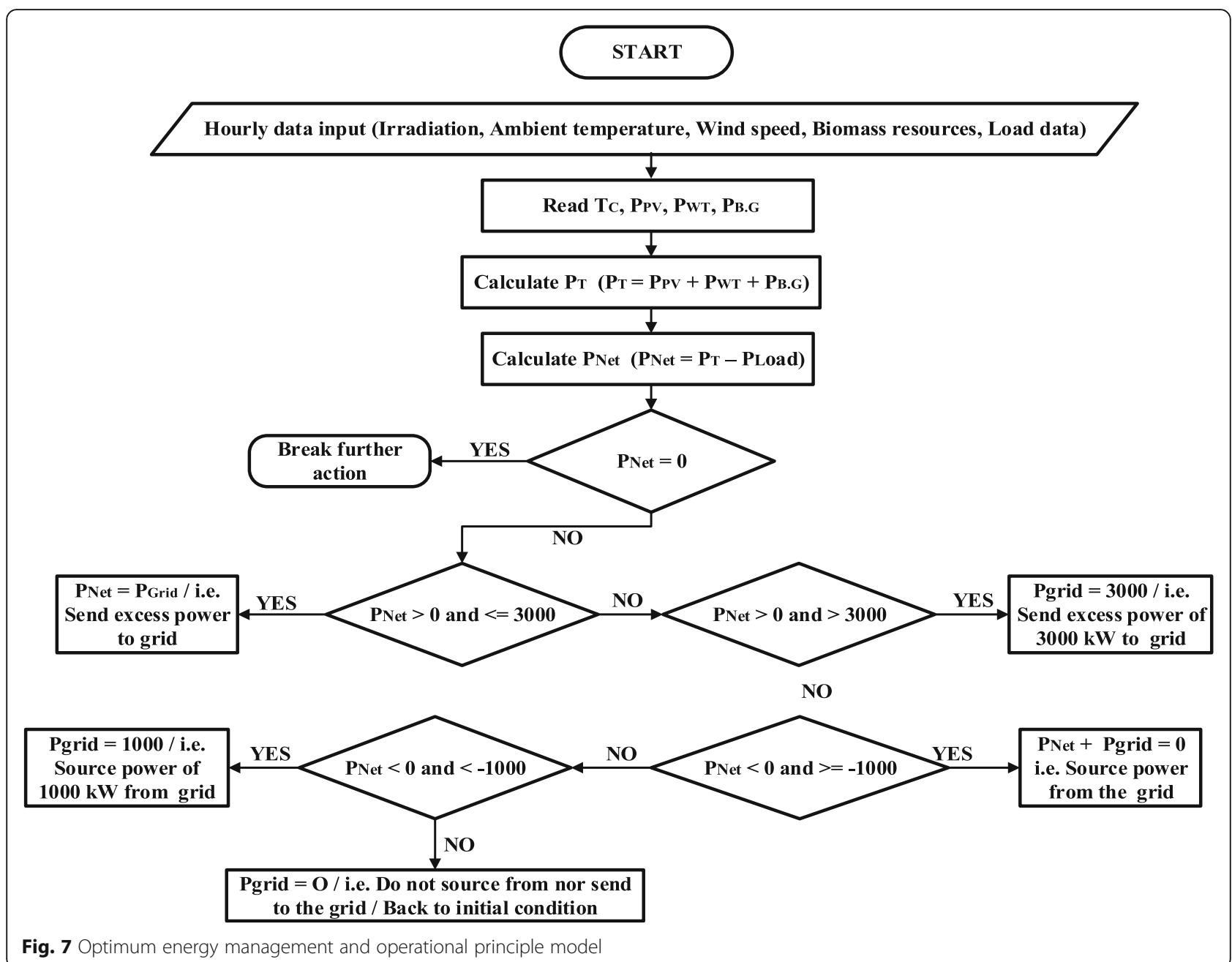

emitting diode (LED)." However, for the heating aspect, the switching was specified from electric cooking and electric water heating regarding the use of an "improved biomass cook stove (IBCS)" for both cooking and water heating. In all the cases, the power demand and cost implications were analyzed and summarized in the Appendix section in Table 16.

Furthermore, supplementary economic assessments were successfully performed using Microsoft Excel for analyzing the economic benefits associated with the switch from the comparable standalone system to the proposed grid-connected system, and also from the proposed grid-connected system to its energy efficiency measure. In the same vain, the assessment of supplementary emissions was successfully carried out using the $\mathrm{GaBi}$ tool for a further analysis of impact categories, e.g., global warming potential (GWP), acidification potential (AP), and ozone-layer depletion potential (ODP) indicators for the proposed gridconnected system and its energy efficiency measure all from the grid-only power supply, i.e., the power supply of the conventional system mixture, available in the utility grid of the country. This enables us to observe the overall environmental impact of the transition throughout a life cycle. Figure 17 of the Appendix section clearly illustrates the model applied in the $\mathrm{GaBi}$ tool for the analysis of the life cycle emission impacts.

Finally, a wrap-up qualitative assessment focusing on the reliability issue for the utility grid and on overall policy implications, in such energy system practices, for the case study country was included.

The project life was taken as 25 years, and the interest rate for the overall economic assessment in the study was assumed to be $6 \%$ as a conventional setting. The additional input data referenced in the methodology can be accessed in the Appendix section with citations where necessary.

\section{Results and discussion}

The results of the overall analyses for the hybrid energy system of the considered site in Nigeria were successfully obtained. These include the results for the 
Table 5 Categorized optimized configurations for the comparable off-grid system

\begin{tabular}{llllllllll}
\hline PV $(\mathrm{kW})$ & Wind $(\mathrm{kW})$ & B. Gen $(\mathrm{kW})$ & Bat. & Conv. (kW) & I. Cap. (\$) & NPC (\$) & RF & Biomass used $(t)$ & B. Gen/h \\
\hline $\mathbf{1 5 0 0}$ & $\mathbf{3 0}$ & $\mathbf{3 5 0 0}$ & $\mathbf{1 5 0}$ & $\mathbf{1 0 0 0}$ & $\mathbf{1 5 . 2} \mathbf{M}$ & $\mathbf{5 1 . 6} \mathbf{M}$ & $\mathbf{1 . 0 0}$ & $\mathbf{1 6 , 2 3 2}$ & $\mathbf{4 1 9 4}$ \\
N/A & 30 & 3500 & 150 & 400 & $10.3 \mathrm{M}$ & $54.3 \mathrm{M}$ & 1.00 & 19,585 & 5074 \\
2,00 & & 150 & 1200 & $12.9 \mathrm{M}$ & $62.4 \mathrm{M}$ & 1.00 & 22,740 & 5672 \\
600 & 20 & 3500 & & 400 & $11.9 \mathrm{M}$ & $63.7 \mathrm{M}$ & 1.00 & 22,672 & 5951 \\
& 30 & 3500 & & & $9.83 \mathrm{M}$ & $65.3 \mathrm{M}$ & 1.00 & 24,302 & 6379 \\
\hline
\end{tabular}

proposed grid-connected system and the comparable off-grid system, sensitivity results, energy efficiency results, and the supplementary analysis results as follows:

\section{Optimization results of the proposed and the comparable system}

The categorized optimization results for the proposed grid connected system and the comparable off-grid system are presented in Tables 5 and 6.

The simulation and optimization results clearly revealed the most feasible optimized configuration with a PV of $1500 \mathrm{~kW}$ capacity, a converter of $1000 \mathrm{~kW}$, 150 batteries, 30 wind turbines of the specified rating, and a biogas genset of $3500 \mathrm{~kW}$ capacity for the comparable off-grid scenario. This is in contrast to the proposed grid-connected system where its most feasible optimized configuration was a $2000 \mathrm{~kW}$ capacity for the PV component with its accompanied converter of a size of $1000 \mathrm{~kW}, 30$ wind turbines with similar specified ratings, and a $2500 \mathrm{~kW}$ capacity for the biogas genset component. The in-depth results for the further technical, economic, and emission parameters are presented in Figs. 8, 9, 10, and 11.

The results clearly show the other technical and economic parameters determined. Looking at the proposed grid-connected system, it is obvious that the total yearly energy supply amounted to $17,353 \mathrm{MWh}$, which incorporated both utility-grid sourced or purchased energy as well as the energy produced by the system components. The yearly energy consumption is found to be 14,978 MWh as the sum of the load utilization and grid utilization as well as excess generations. This is relatively comparable to the off-grid scenario, where the supplied energy from its system component is found to be slightly more and with more excess generations than that of the proposed grid-connected system. Moreover, the fuel consumption in favor of the proposed grid-connected system has obviously reduced by around $40 \%$ due to an obvious reduction in the optimized capacity rating for the biogas genset from 3500 to $2500 \mathrm{~kW}$. These technical performance parameters observed must certainly affect the economics of the system resulting in a huge reduction in the NPC as well as the LCOE values by roughly $68 \%$ and $67 \%$, respectively. The environmental or emission parameter has further shown more benefits in the grid-connected system, in which the greenhouse gas emission value became negative as compared to the off-grid's slightly positive value. The implication of the negative greenhouse gas emission of the system is the avoided emission as a result of the grid interaction, based on the substituted fossil power from the grid that is a high contributor to greenhouse gas emissions at the operational stage. The specified positive emission value for the comparable off-grid case was due to the presence of the biogas genset with its associated direct emission at the operational level as compared to the life cycle basis where the direct emissions turned to neutral. The emission evaluation formulae for the two systems are displayed in the figure of emissions, i.e., Fig. 11.

\section{Sensitivity results for the analysis of the proposed grid- connected system}

The sensitivity analysis results were successfully confirmed for the different parameters considered. When starting with the economic-based sensitivity and varying the discount rate obviously affected the operating costs, and ultimately the NPC (that is also linked with the operating costs and the LCOE) as shown in Table 7). It is clear that an increase in the discount rate decreases the NPC, as well as ultimately the LCOE and the operating costs.

When turning our attention to the technical and climate-based parameters, beginning with the scaled annual average solar irradiation sensitivity result as presented in Table 8 , it is obvious that a change affected many other parameters in the system performance. The scaled annual average irradiance

Table 6 Categorized optimized configurations for the proposed grid-connected system

\begin{tabular}{llllllllll}
\hline PV $(\mathrm{kW})$ & Wind $(\mathrm{kW})$ & B. Gen $(\mathrm{kW})$ & Conv $(\mathrm{kW})$ & Grid $(\mathrm{kW})$ & I. Cap. (\$) & NPC (\$) & RF & Biomass used (t) & B. Gen/h \\
\hline $\mathbf{2 0 0 0}$ & $\mathbf{3 0}$ & $\mathbf{2 5 0 0}$ & $\mathbf{1 0 0 0}$ & $\mathbf{1 0 0 0}$ & $\mathbf{1 4 . 8} \mathbf{M}$ & $\mathbf{1 6 . 7} \mathbf{M}$ & $\mathbf{0 . 9 5}$ & $\mathbf{9 7 9 8}$ & $\mathbf{1 7 2 2}$ \\
\hline
\end{tabular}




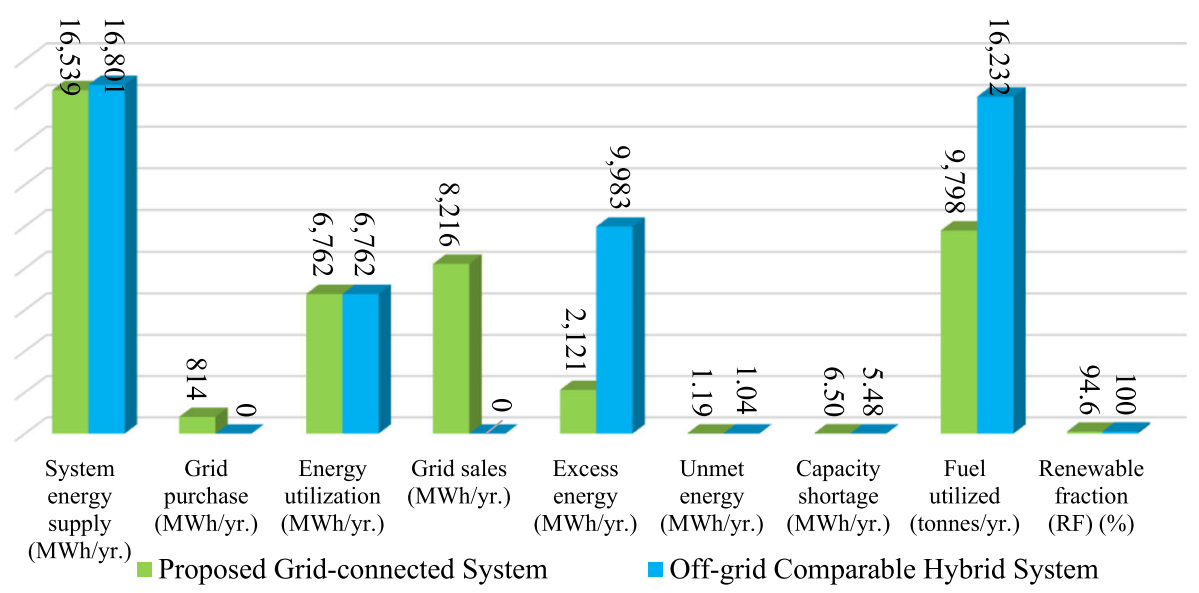

NB: Energy Supply Components Ratio (Off-grid system: PV: 14.60\%, Wind T: 56.15\%, Biogenset:29.25\% / Proposed Grid-connected System: PV: 19.78\%, Wind T: 57.04\%, Biogenset:23.18\%)

Fig. 8 Technical parameter results for the proposed system and comparable system. Energy supply component ratio (off-grid system: PV 14.60\%, wind T, 56.15\%, and bio-genset 29.25\%/proposed grid-connected system: PV 19.78\%, wind T 57.04\%, and bio-genset 23.18\%)

increase only influences the optimized sizing for the system component at $6.06 \mathrm{kWh} / \mathrm{m}^{2} /$ day, where the sizing for solar PV and the bio-genset changed. Likewise, the solar PV energy production increased with an increase in the irradiance value all throughout, which triggered a decrease in the bio-genset production due to the flexible nature of the operating hours for the genset when being optimized in dependence on the energy supply of other components. The irradiance changes also affected the economic parameters as well as the grid energy purchase and the sales with a decrease for every increase in the irradiance value. When considering the scaled annual wind speed variations given in Table 9, the optimized sizing for solar PV would be affected. This is true in view of re-adjustments of other components for meeting the demand in a most economic manner. The energy production values for the different

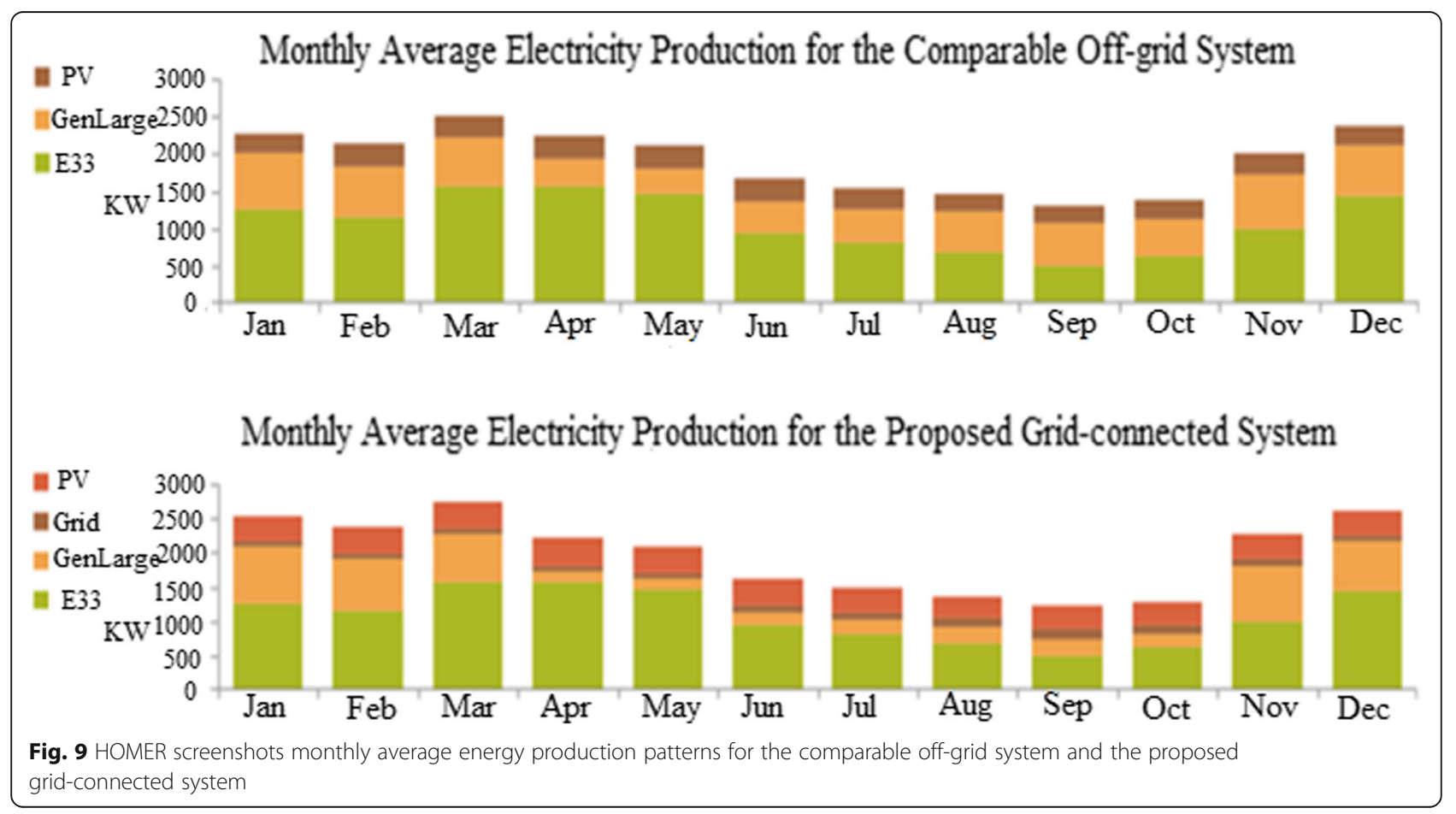




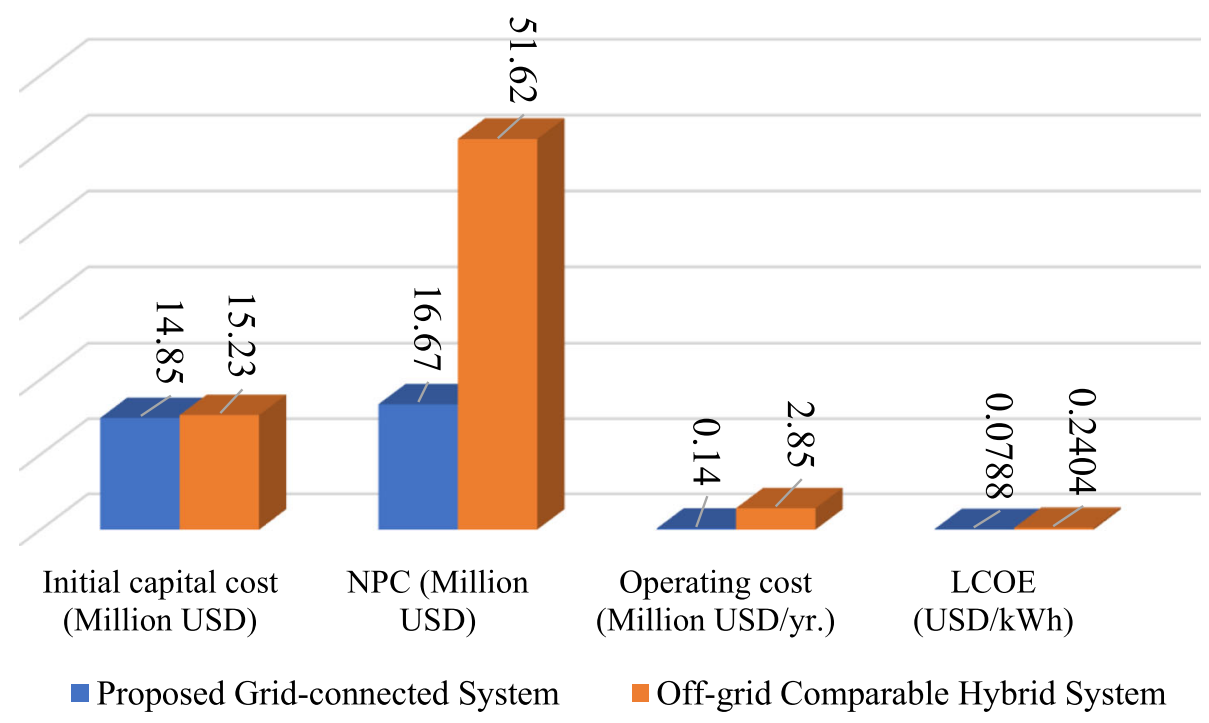

Fig. 10 Economic parameter results for both the proposed and the comparable system (Excel-based)

components all varied, which affected the economic parameters as well as the grid energy purchases and sales. The last parameter considered in the sensitivity was the ambient temperature that is linked to the irradiation data in the modeling. The results are listed in Table 10. These parameters indicate that the solar PV energy supply was affected in an inverse proportion manner. This is due to the increased temperature impact on the performance of solar PV modules which lowers their efficiencies. The biogenset energy supply was observed to increase based on the hours of operation changed for ensuring the most economically optimum generation. Ultimately, the grid energy purchase and sales were also modified but mostly in a decreasing manner.

\section{Results of energy efficiency (EE) assessment}

The analyzed input specifications with regard to the energy efficiency assessment are given in the Appendix section of Table 16 The detailed breakdown of the results is presented in Figs. 12, 13, 14, and 15 for the in-depth technical, economic, and emission aspects. The baseline optimized configurations for the proposed grid-connected system previously worked out included a PV $(2000 \mathrm{~kW})$, a converter $(1000 \mathrm{~kW})$, 30 wind turbines of the same specified rating, and a biogas genset $(2500 \mathrm{~kW})$. The optimized configurations achieved by an energy efficiency analysis revealed a reduction of the genset component to a capacity of $800 \mathrm{~kW}$, and a reduced solar PV component size of up to $400 \mathrm{~kW}$, when a converter of 200 $\mathrm{kW}$ was used and the size of the wind turbine was left unchanged.

The reduction in the optimized component sizing for the new load demand, arising from an efficient switching of appliances resulted in an energy supply reduction by $37 \%$ (i.e., from 16,539 to $10,397 \mathrm{MWh} /$

\section{Calculated Net GHG emission / CO2 (tonnes/yr.)}

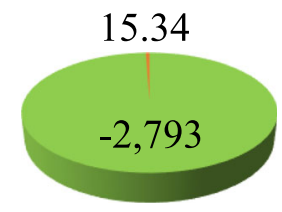

$\square$ Proposed Grid-connected System

- Off-grid Comparable Hybrid System
Net Emissions / Avoided Emissions for the Utility Grid Case $=(P-S)\left(X_{G . C . E}-Y^{*} X_{\text {G...R.E }}\right)$ Where: $\mathbf{P}=$ Purchased Energy from the Grid $(\mathrm{kWh} / \mathrm{yr}$.), $\mathbf{S}=$ Sold Energy to the Grid $\left(\mathrm{kWh} / \mathrm{yr}\right.$.), $X_{\text {G.C.E }}=$ Emission factor for Grid Conventional Energy $(\mathrm{kg} / \mathrm{kWh}$ elec. $), X_{\text {G.I.R.E }}$ $=$ Emission factor for the Grid-in Renewable Energy $\left(\mathrm{kg} / \mathrm{kWh}_{\text {elec. }}\right), Y=\%$ share of biogenset in the Energy Supply.

Net Emissions / Direct Emissions for the Off-grid System Operation $=T * Y * X_{R . E}$ Where: $\mathbf{T}=$ Total Electricity Generated by the System $\left(\mathrm{kWh} / \mathrm{yr}\right.$.) $\mathbf{X}_{\mathrm{R} . \mathrm{E}}=$ Emission factor for the Renewable Energy $(\mathrm{kg} / \mathrm{kWh} \mathrm{elec}), Y=\%$ share of biogenset in the Electricity Supply

Fig. 11 The evaluated emissions for the proposed and the comparable system 
Table 7 Discount rate sensitivity results

\begin{tabular}{llll}
\hline Discount rate & NPC $(\$)$ & $\begin{array}{l}\text { LCOE }(\$ / \mathrm{kWh}) / \\
\text { Excel-based }\end{array}$ & $\begin{array}{l}\text { Operating costs }(\$ / \text { year }) / \\
\text { Excel-based }\end{array}$ \\
\hline $4 \%$ & $17.2 \mathrm{M}$ & 0.0812 & $148,491.8$ \\
$5 \%$ & $16.9 \mathrm{M}$ & 0.0799 & $145,857.7$ \\
$6 \%$ & $16.7 \mathrm{M}$ & 0.0788 & $142,339.8$ \\
$7 \%$ & $16.5 \mathrm{M}$ & 0.0778 & $138,046.0$ \\
$8 \%$ & $16.3 \mathrm{M}$ & 0.0769 & $133,081.9$ \\
\hline
\end{tabular}

year). This also ultimately influenced the consumption as clearly demonstrated in Fig. 12. Regarding fuel consumption, a reduction of around $44 \%$ was noticed in favor of the energy efficiency case. The economic parameters, specifically the NPC, were drastically reduced by $88 \%$, and the LCOE by $81 \%$ despite the associated cost implications of the energy efficiency measures. However, the greenhouse gas emissions were observed to be reduced by around 34\% based on the displayed emission formula in Fig. 15 and should be seen as a result of the reduced net proposed grid-connected system was close to $\$ 35$ million. This amount, based on the annuity analysis that incorporated the discount factors, the capital recovery factor, and the project life span led to a simple payback period (PBP) of about 6 years, as well as a discounted payback period (DPBP) of about 7 years. These payback periods (i.e., DPBP and PBP) could be interpreted as the years required for securing back the total costs for the implementation of the proposed grid connected system from the saved amount of

Table 8 Scaled annual average solar resources sensitivity results

\begin{tabular}{|c|c|c|c|c|c|c|c|c|c|}
\hline $\begin{array}{l}\text { Solar resources } \\
\left(\mathrm{kWh} / \mathrm{m}^{2} / \text { day }\right)\end{array}$ & $\begin{array}{l}\text { PV } \\
\text { Cap. } \\
\text { (kW) }\end{array}$ & $\begin{array}{l}\text { B. genset } \\
\text { Cap. (kW) }\end{array}$ & $\begin{array}{l}\text { PV supply } \\
\text { (MWh/year) }\end{array}$ & $\begin{array}{l}\text { B. genset supply } \\
\text { (MWh/year) }\end{array}$ & $\begin{array}{l}\text { Grid energy (MWh) } \\
\text { (purchase/sales) }\end{array}$ & $\begin{array}{l}\text { Initial } \\
\text { costs } \\
\text { (\$) }\end{array}$ & $\begin{array}{l}\text { NPC } \\
(\$)\end{array}$ & $\begin{array}{l}\text { LCOE }(\$ / k W h) / \\
\text { Excel-based }\end{array}$ & $\begin{array}{l}\text { Operating cost } \\
\text { (\$/year)/Excel-based }\end{array}$ \\
\hline 5.49 & 2000 & 2500 & 3110 & 3861 & $815 / 8173$ & $14.8 \mathrm{M}$ & $\begin{array}{l}16.8 \\
M\end{array}$ & 0.0801 & $152,494.4$ \\
\hline 5.78 & 2000 & 2500 & 3272 & 3833 & $814 / 8216$ & $14.8 \mathrm{M}$ & $\begin{array}{l}16.7 \\
M\end{array}$ & 0.0788 & $142,339.8$ \\
\hline 6.06 & 2500 & 2200 & 3934 & 3709 & 789/8139 & $16.0 \mathrm{M}$ & $\begin{array}{l}16.1 \\
M\end{array}$ & 0.0724 & $11,104.3$ \\
\hline
\end{tabular}

energy of the system available in the grid.

\section{Results of the analysis of supplementary economic benefits and emissions}

The supplementary economic benefits of the proposed grid-connected system compared to the base case standalone system were analyzed using Microsoft Excel and showed amazing outcomes in Table 11. It is obvious that the net of the NPC values indicating the saved amount of money in the transitioning to the money in the systems that were switched both with and without discounting, respectively. Ultimately, a return on investment in the switch-over was estimated to be around $16 \%$, which is close to the internal rate of return.

Similarly, in ascertaining the benefits of adopting the energy efficiency to the proposed grid-connected system, based on the saved amount of money in such a switch-over from the grid-connected system, and being the base case in this regard, similar analysis parameters

Table 9 Scaled annual average wind resources sensitivity results

\begin{tabular}{|c|c|c|c|c|c|c|c|c|c|}
\hline $\begin{array}{l}\text { Wind } \\
\text { resources }(\mathrm{m} / \mathrm{s})\end{array}$ & $\begin{array}{l}\text { PV Cap. } \\
(\mathrm{kW})\end{array}$ & $\begin{array}{l}\text { Wind T. supply } \\
\text { (MWh/year) }\end{array}$ & $\begin{array}{l}\text { PV supply } \\
\text { (MWh/year) }\end{array}$ & $\begin{array}{l}\text { B. genset supply } \\
\text { (MWh/year) }\end{array}$ & $\begin{array}{l}\text { Grid energy (MWh) } \\
\text { (purchase/sold) }\end{array}$ & $\begin{array}{l}\text { Initial } \\
\text { costs }(\$)\end{array}$ & $\begin{array}{l}\text { NPC } \\
(\$)\end{array}$ & $\begin{array}{l}\text { LCOE }(\$ / k W h) / \\
\text { Excel-based }\end{array}$ & $\begin{array}{l}\text { Operating cost } \\
\text { (\$/year)/Excel-based }\end{array}$ \\
\hline 3.55 & 3000 & 8080 & 4907 & 3900 & $825 / 8554$ & $18.2 \mathrm{M}$ & $\begin{array}{l}20.1 \\
M\end{array}$ & 0.0933 & $151,634.7$ \\
\hline 3.74 & 2000 & 9434 & 3272 & 3833 & $814 / 8216$ & $14.8 \mathrm{M}$ & $\begin{array}{l}16.7 \\
M\end{array}$ & 0.0788 & $142,339.8$ \\
\hline 3.93 & 1200 & 10,827 & 1963 & 3826 & $809 / 8186$ & $12.2 \mathrm{M}$ & $\begin{array}{l}13.7 \\
M\end{array}$ & 0.0647 & $123,599.0$ \\
\hline
\end{tabular}


Table 10 Scaled annual average ambient temperature sensitivity results

\begin{tabular}{llll}
\hline Ambient temperature $\left({ }^{\circ} \mathrm{C}\right)$ & $\begin{array}{l}\text { PV supply } \\
(\text { MWh/year) }\end{array}$ & $\begin{array}{l}\text { Bio-genset supply } \\
\text { (MWh/year) }\end{array}$ & $\begin{array}{l}\text { Grid energy (MWh) } \\
\text { (purchase/sold) }\end{array}$ \\
\hline 23.7 & 3291 & 3831 & $813 / 8220$ \\
25.0 & 3272 & 3833 & $814 / 8216$ \\
26.2 & 3253 & 3838 & $813 / 8212$ \\
\hline
\end{tabular}

were achieved. The saved amount being close to $\$ 15$ million in the switch-over led to a payback period of 1.78 years, a discounted payback period of 1.99 years, and ultimately to a return on investment as well as an internal rate of return of all approximately $56 \%$. The impact in this scenario is even more rewarding as compared to the impact in the preceded analysis of the grid-connected system to the base case standalone system. This is due to a lesser number of years in the recovery of the total investments and a greater return. Table 12 summarized the entire results of the excel analysis in the comparison.

The supplementary emission analysis, which is based on the global warming potential (GWP), the acidification potential (AP), and the ozone-layer depletion potential (ODP) indicators as determinants for slightly broader environmental impacts over the entire life cycle proved to be successful. The results are depicted in Fig. 16. It is evident that a comparison of the proposed system with a grid-only power production system based on a unit kilowatt hour of electricity revealed a gap in the overall life cycle greenhouse gas emission savings with regard to the reduction of the $\mathrm{CO}_{2}$-equivalent from the grid-only power that is comprised of more fossil fuels in the mixture. The same applies to the acidic gas emissions with an acidification potential gap shown on a life cycle basis.
It is also obvious that the energy efficiency measure for the proposed grid-connected system has become a reduced GWP, and AP value per unit kilowatt hour of energy production. This is due to the resizing of the system in favor of a higher wind power production share and reduced shares for the biogas and solar PV power, as compared to the optimal sizing of the grid-connected system. However, the AP gases are applied on both a direct and an indirect basis to the proposed hybrid renewable system with its EE measure, unlike the GWP where only the indirect-based emissions apply due to the carbon neutrality of the renewable systems. Regarding the ODP indicator incorporated, it favors grid-only power, although all values being infinitesimal. This is because this potential indicator applies primarily to the solar PV activities in the life cycle, while still affecting the proposed hybrid renewable system with its EE measure. The EE case impact value on the ODP category is observed to be relatively less compared to that of the proposed system prior to the EE incorporation. This is obviously due to the share of the PV energy production being reduced in the optimization process.

\section{Qualitative analysis of the overall findings}

On extending the power system modeling task, a brief qualitative assessment based on reliability arguments

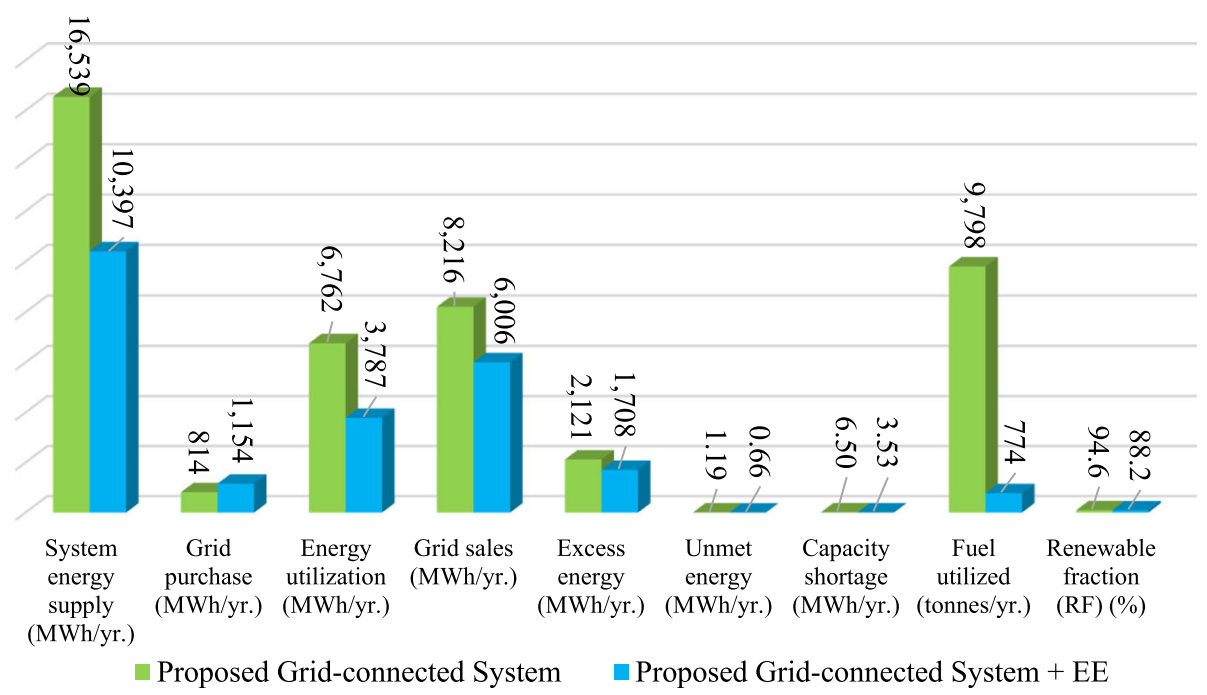

Fig. 12 Technical parameter results for the proposed system and its EE measures. Energy supply component ratio (proposed grid-connected system: PV 19.78\%, wind T 57.04\%, and bio-genset 23.18\%/proposed grid-connected system + EE: PV 6.29\%, WT 90.74\%, and bio-genset 2.97\%) 


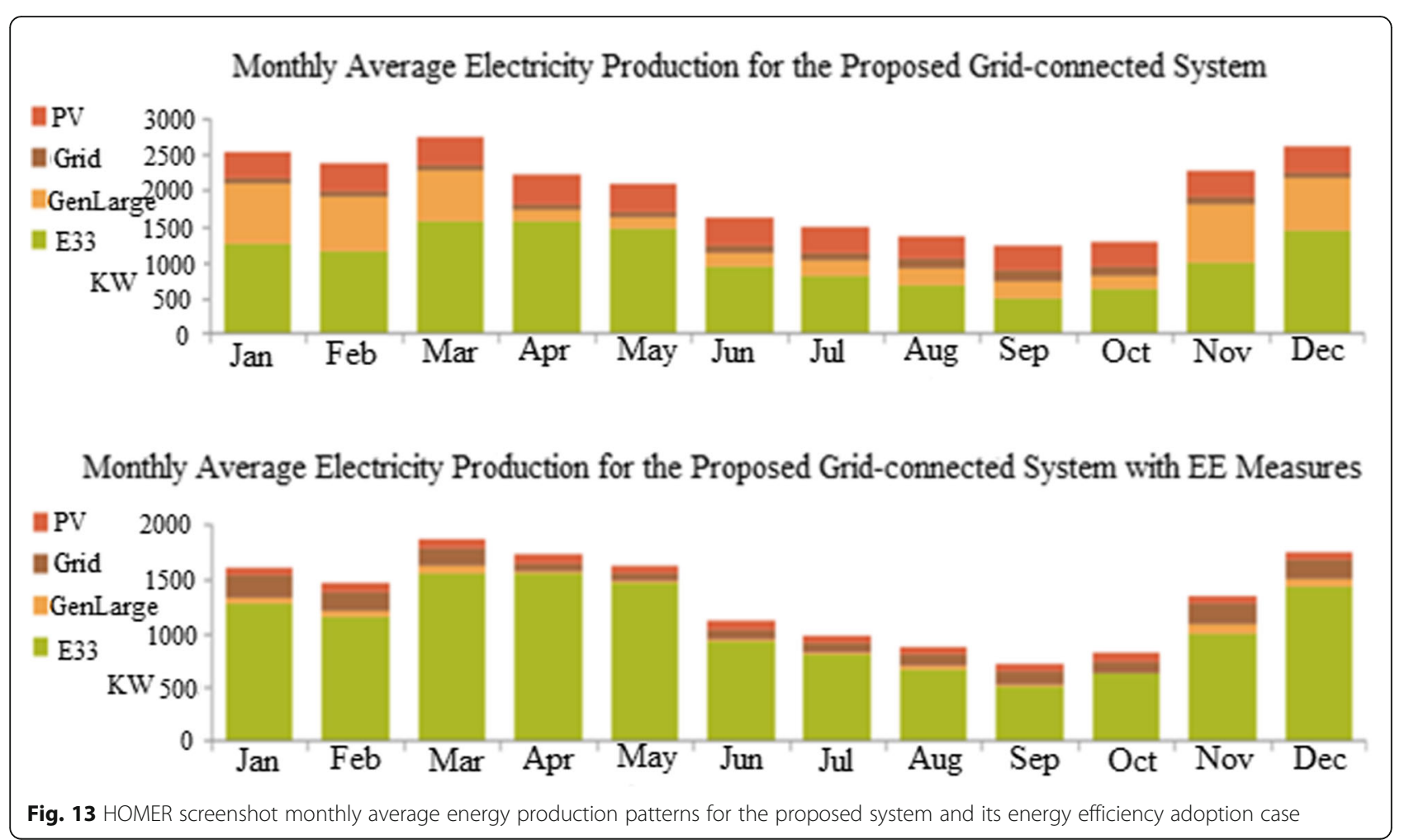

to the case study country is also essential. This is based on the utility grid concerns and the policy implications of such energy solutions proposed. Firstly, the Nigerian gridinfrastructure focusing on the transmission network had a theoretical capacity of $7500 \mathrm{MW}$ but can handle a wheeling capacity of $4500 \mathrm{MW}$ over a distance of about 20,000 $\mathrm{km}[35,36]$. This is said to be insufficiently low and requires significant expansion and integration of the renewable systems in addressing energy deficits, environmental concerns, and so on. However, challenges regarding the utility grid consist of not only the wheeling capacity shortage but also other concerns, namely network transmission

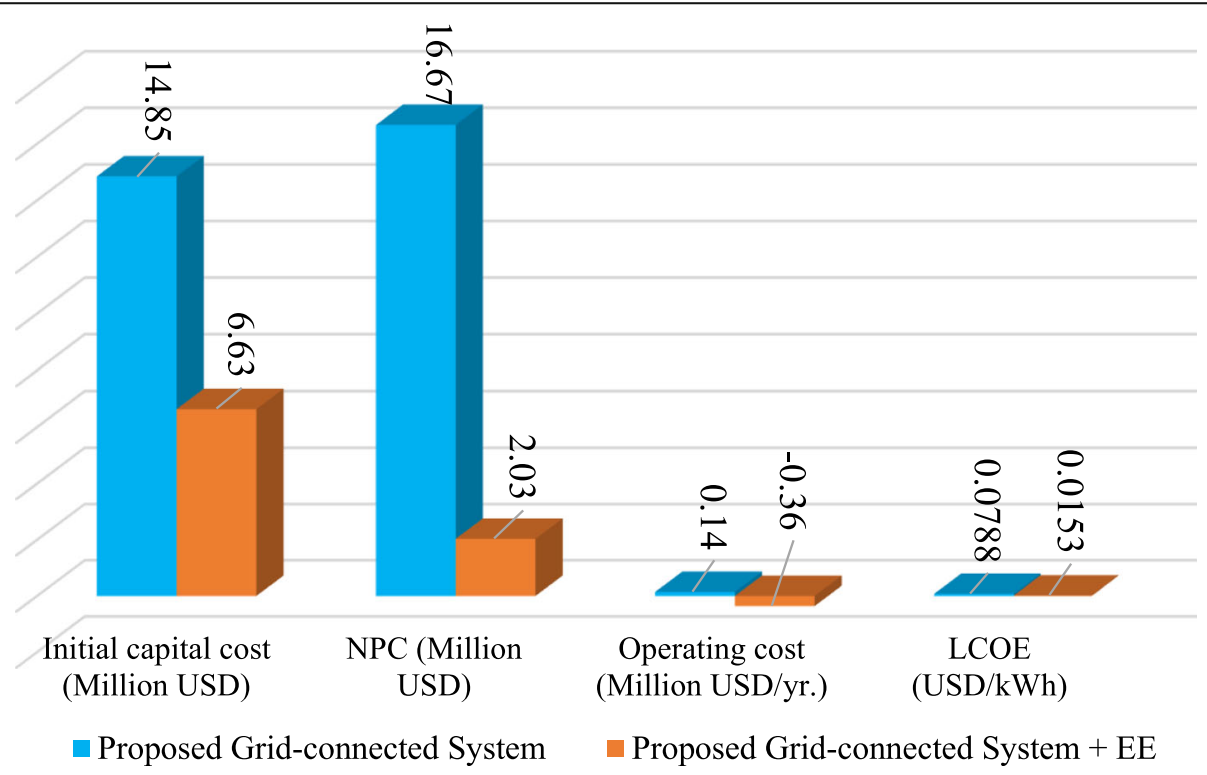

Fig. 14 Economic parameter results for the proposed system and its EE measures (Excel-based) 
Calculated Net GHG emission / CO2 (tonnes/yr.)

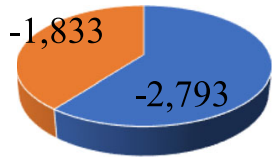

Net Emissions / Avoided Emissions for the Utility Grid Case $=(P-S)\left(X_{G . C . E}-Y^{*} X_{\text {G.I.R.E }}\right)$ Where: $\mathbf{P}=$ Purchased Energy from the Grid $(\mathrm{kWh} / \mathrm{yr}$.), $\mathbf{S}=$ Sold Energy to the Grid $\left(\mathrm{kWh} / \mathbf{y r}\right.$.), $X_{\text {G.C.E }}=$ Emission factor for Grid Conventional Energy $\left(\mathrm{kg} / \mathrm{kWh} \mathrm{h}_{\text {elec. }}\right)$, $X_{\text {G.I.R.E }}$ $=$ Emission factor for the Grid-in Renewable Energy $(\mathrm{kg} / \mathrm{kWh}$ elec $), Y=\%$ share of biogenset in the Energy Supply

- Proposed Grid-connected System

- Proposed Grid-connected System + EE

Fig. 15 The evaluated avoided emissions for the proposed system and its EE measures

losses on an average of $7.4 \%$, being higher than those of emerging countries' benchmarked at $2-6 \%[35,36]$, persistent power cuts arising from the inefficiency of power evacuations, voltage control challenges, poor maintenance, and inadequate mesh networks $[4,37]$. Hence, these might serve as limitations to the integration of the hybrid system at the moment despite its outstanding benefits compared to the comparable standalone hybrid system case discussed previously in the quantitative analysis. Thus, adopting the comparable off-grid system is also a good idea for the power supply of the demand site(s), until the utility grid challenges are resolved. Addressing the utility grid challenges for continuous operation stability requires strong measures such as investment on technology transfer, continuous research, adequate financing, and highly skilled manpower, which goes back to the political will of the Nigerian government.

On moving to the policy aspect, which is also a strong indicator for the successful transition, it is obvious that the solution targeted both consumption and grid intervention at the domestic level, hence a bidirectional approach, which is closely associated with net metering as a policy instrument. Currently, this policy instrument does not exist in the country; however, a closer instrument to it, being the feed-in tariff exists, which was approved in 2015 and put to force in 2016, covering solar PV, wind turbines, small hydro, and biomass power [38]. Therefore, as a call, the net metering instrument

Table 11 Economic benefit analysis of the proposed gridconnected system compared to the base case off-grid system (Excel results)

\begin{tabular}{ll}
\hline Analyzed parameters & Specification \\
\hline Calculated capital recovery factor (CRF) & 0.0782 \\
Net of NPC as benefit of the switch to & $\$ 34.96 \mathrm{M}$ \\
the proposed grid-based system & \\
Calculated annualized value of the benefit & $\$ 2.73 \mathrm{M}$ \\
Calculated payback period (PBP) & 6.09 years \\
Discounted payback period (DPBP) & 7.18 years \\
Calculated rate of return (ROI) & $16.41 \%$ \\
Calculated internal rate of return (IRR) & $16 \%$ \\
\hline
\end{tabular}

is also needed for such grid integration, particularly for those venturing into the power system business as consumers at the same time for offsetting costs, efficient operation, and ensuring sustainable power supply on the grid-intervention. This should take a favorable package far beyond the conventional electricity price, for the kilowatt hour of net power provided to the grid. It should be mentioned that for the sake of this study, the purchase price was specified in the utility grid inputs as $150 \%$ of the conventional power purchase price as a minimum for a better motivation of such ventures. Again, concerning the energy efficiency assessment addressed, it showed a tremendous outcome technically and economically. Hence, such practice is also necessary and needs appropriate incentives from the government for its diffusion and sustainability. The incentives could be made effective through the launch of different programs and sensitizations while clearly specifying the packages necessary for such practices by the energy consumers at the domestic level and beyond. Additionally, full financing for the systems' venture could also be made available as a further motivation where the full payback by the energy producers could then be favored by many installments over a long-term period.

\section{Conclusion}

Detailed assessment of a grid-connected hybrid renewable power system has been proposed and

Table 12 Economic benefit analysis of the switch from the grid-connected system to the EE-based system (Excel results)

\begin{tabular}{ll}
\hline Analyzed parameters & Specification \\
\hline Calculated capital recovery factor (CRF) & 0.0782 \\
Net of NPC as benefit of the system & $\$ 14.63 \mathrm{M}$ \\
switch to EE-based system & \\
Calculated annualized value of the benefit & $\$ 1.14 \mathrm{M}$ \\
Calculated payback period (PBP) & 1.78 years \\
Discounted payback period (DPBP) & 1.99 years \\
Calculated rate of return (ROI) & $56.25 \%$ \\
Calculated internal rate of return (IRR) & $56 \%$ \\
\hline
\end{tabular}




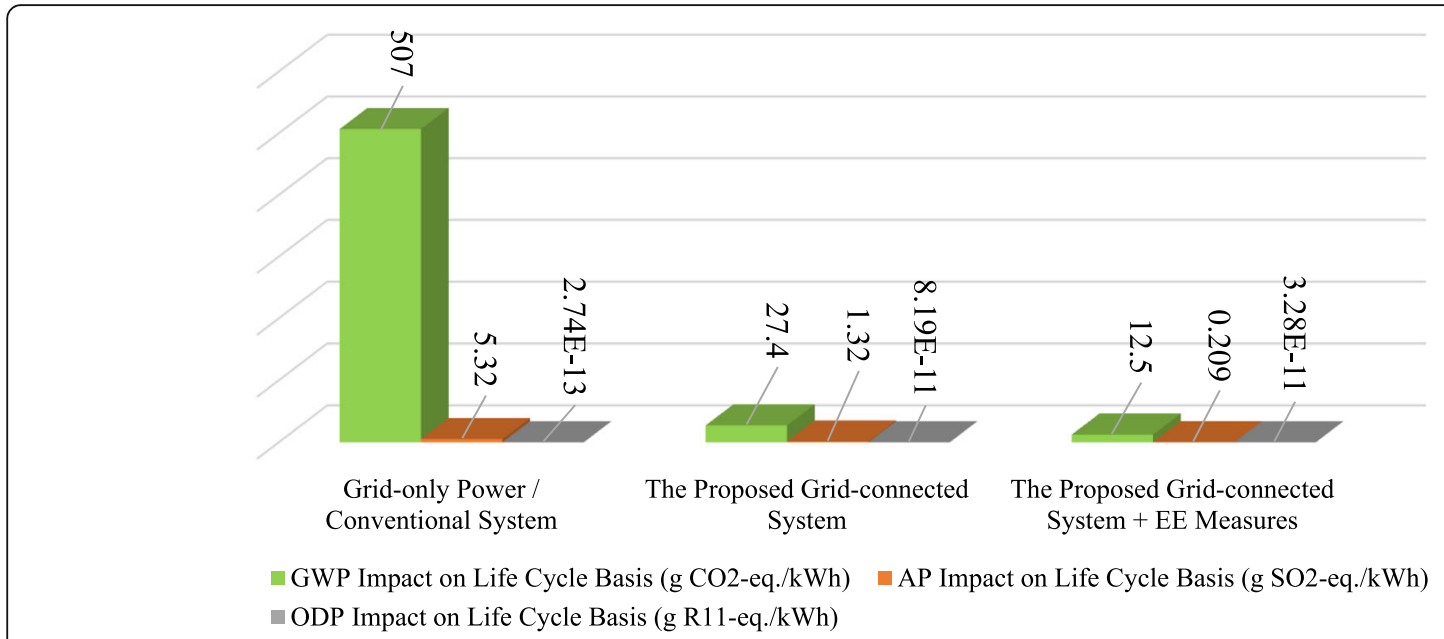

Fig. 16 Supplementary life cycle emission indicator results of the systems

conducted with its comparison to an off-grid hybrid renewable power system for obtaining clear benefits of the successful transition. The assessment was based on techno-economic modeling and optimization, sensitivity analysis, energy efficiency assessment, further supplementary economic and life cycle emissions evaluation, as well as a wrap-up reliability argument.

The optimized configuration for the proposed gridconnected system for addressing the considered load profile for the site was found at a total energy production of $16,539 \mathrm{MWh} /$ year, and a total supply of 17 , $353 \mathrm{MWh} /$ year due to the additional grid purchase of $814 \mathrm{MWh} /$ year. Load consumption was estimated to be $6762 \mathrm{MWh} /$ year and grid injection $8216 \mathrm{MWh} /$ year. The NPC as well as the LCOE for the system were $\$ 16.67$ million and $\$ 0.0788 / \mathrm{kWh}$ respectively. These NPC and LCOE values were observed to be roughly $68 \%$ and $67 \%$ respectively, less than those of the comparable off-grid system. This was caused by the grid impact on the proposed system, as excess energy could be sent to the grid in offsetting the overall system costs despite the need to purchase energy on occasions of deficits. This is different to the off-grid system where the additional battery increases the system costs, without possibilities of grid intervention. Another benefit was observed regarding the massive reduction in greenhouse gas emissions to the point of even eliminating emissions for the grid system at the operational level. The technical and economic parametric sensitivity analysis also revealed an impact on other parameters and the extent of such an impact on the system operation. The energy efficiency assessment with further simulation and re-optimization indicated a tremendous decrease in the optimized sizing, energy production, and economic parameters, hence an opportunity for a credible and commendable transition. The decrease in the economic parameters in the EE implementation for the grid-connected system was found to be as high as by $88 \%$ and $81 \%$ for the NPC and LCOE, respectively. Nevertheless, the avoided emissions in the grid, based upon the $\mathrm{EE}$ assessment, were reduced due to a reduction in the excess energy of the system available in the grid.

An evaluation of the further supplementary economic benefits considering the saved cash in systems switching showed impacts on different economic parameters, namely the payback period, the discounted payback period, the rate of return, and the internal rate of return. At the same time, further supplementary assessments based on the life cycle emissions impact also clearly showed a gap of the proposed system and its energy efficiency measures compared to the grid-only power. This is due to the carbon neutrality of the renewable-based system and the carbon positivity of the conventional-based systems in the grid in view of the analyzed GWP case as an example. Nevertheless, indirect emissions were accounted for all the aspects of the life cycle in line with the concerned processes from the GaBi software database.

These all are obvious for the relevance of implementing a hybrid renewable energy system with grid integration on decentralized grounds. There is also a strong need for implementing the energy efficiency measures evident for achieving enormous benefits in line with a low-carbon development transition. This could be successfully fulfilled using not only a reliable utility grid and commendable policy measures' supports but also strong incentive measures, in particular, for ensuring the energy efficiency practices at the considered domestic level and beyond. 


\section{Appendix}

\section{The component modeling input data}

Table 13 Utility grid input specifications

\begin{tabular}{lll}
\hline Parameter & Specification & Remark/reference \\
\hline Purchase price $(\$ / \mathrm{kWh})$ & 0.06 & {$[35]$} \\
Sellback price $(\$ / \mathrm{kWh})$ & $150 \%$ of 0.06 & For better motivations to renewable energy projects \\
Net metering & Net purchase & On monthly basis as a choice \\
Emissions $(\mathrm{g} / \mathrm{kWh})$ & $\mathrm{CO}_{2}, 378 ; \mathrm{CO}, 0.03 ; \mathrm{SO}_{2}, 1.9 ; \mathrm{NO}_{x}, 0.41 ; \mathrm{PM}, 0.14$ & $\begin{array}{l}\text { Calculated based on the country's electricity mix ratio } /[39] \\
\text { Sales capacity }(\mathrm{kW})\end{array}$ \\
3000 & 1000 & $\begin{array}{l}\text { Assumed maximum power to be sold to grid on an event } \\
\text { of excess generation }\end{array}$ \\
Purchase capacity $(\mathrm{kW})$ & & $\begin{array}{l}\text { Assumed maximum power to be purchased from grid on an } \\
\text { event of shortage }\end{array}$ \\
\end{tabular}

Table 14 Input specifications for the power system components

\begin{tabular}{|c|c|c|c|c|}
\hline Components & Costs & Life span & Sizes used & Others \\
\hline $\begin{array}{l}\text { PV panel (Q-Cell } \\
\text { 225/polycrystalline) }\end{array}$ & $\begin{array}{l}\text { C.C, } 3000 \$ / \mathrm{kW} ; \text { R.C, 3000\$/kW; O\&M, } \\
10 \$ / \mathrm{kW} /[31]\end{array}$ & 25 years & Range of (400-3500 kW) & $\begin{array}{l}\text { Efficiency at standard test condition, } 15.3 \% \text {; } \\
\text { nominal operating cell temperature, } 45^{\circ} \mathrm{C} \text {; } \\
\text { temperature coefficient of power, }- \\
0.42 \% /{ }^{\circ} \mathrm{C} \text {; derating factor, } 80 \% \text {; ground } \\
\text { reflectance, } 20 \% /[31]\end{array}$ \\
\hline $\begin{array}{l}\text { Wind turbine } \\
\text { (Enercon E33) }\end{array}$ & $\begin{array}{l}\text { C.C } 131,146.11 \$ \text { /unit; R.C } 128,469.66 \$ / \\
\text { unit; O\&M } \\
1338.23 \$ \text { /unit (updated cost of } 2012 \text { at } \\
6 \% \text { I.R) /[40] }\end{array}$ & 25 years & Range of (1 - 30 units) & $\begin{array}{l}\text { Rated power, 330-335 kW AC; tower height, } \\
50 \mathrm{~m} \text {; cut-in speed, } 3 \mathrm{~m} / \mathrm{s} \text {; rated speed, } \\
13 \mathrm{~m} / \mathrm{s} /[\text { HOMER specification] }\end{array}$ \\
\hline $\begin{array}{l}\text { Biogas power } \\
\text { genset }\end{array}$ & $\begin{array}{l}\text { C.C, } 1685.4 \$ \text { /unit; R.C, } 1348.32 \$ / \text { unit; } \\
\text { O\&M, } 0.11 \$ \text { /unit (composite of the } \\
\text { biodigester and the biogas genset: } \\
\text { updated cost of } 2015 \text { at } 6 \% \text { I.R) /[41] }\end{array}$ & $15,000 \mathrm{~h}$ & Range of (400-3500 kW) & $\begin{array}{l}\text { Minimum load ratio, 30; calculated biogas } \\
\text { intercept coefficient, } 0.1083 \mathrm{~kg} / \mathrm{h} / \mathrm{kW} \text { [ }[42] \text {; } \\
\text { calculated biogas slope, } 0.5685 \mathrm{~kg} / \mathrm{h} / \mathrm{kW} \text { out } \\
\text { [42]; emissions (kg/kg fuel): CO-33, } \\
\mathrm{NO}_{\mathrm{x}}-6.17, \mathrm{PM}-0.00068[43,44]\end{array}$ \\
\hline $\begin{array}{l}\text { Battery (Surette 6CS25P)/ } \\
\text { for the } \\
\text { off-grid case only }\end{array}$ & $\begin{array}{l}\text { C.C, } 1348 \$ \text { /unit; R.C, } 1123.6 \$ \text { /unit; O\&M, } \\
16.85 \$ \text { /unit } \\
\text { (updated costs of } 2015 \text { at } 6 \% \text { I.R) /[41] }\end{array}$ & 12 & Range of (10-150 units) & $\begin{array}{l}\text { Voltage, } 6 \mathrm{~V} \text {; nominal capacity, } 1156 \mathrm{Ah} \text {; } \\
\text { round trip efficiency, } 80 \% \text {; life throughput, } \\
9645 \mathrm{kWh} \text {; min SOC, 40\%; max power, } \\
0.25 \mathrm{~kW} /[\text { HOMER specification] }\end{array}$ \\
\hline Inverter (Generic C) & $\begin{array}{l}\text { C.C, 700\$/unit; R.C, 700\$/unit; O\&M, } \\
10 \$ / \text { unit /[31] }\end{array}$ & 15 & Range of (200-1200 kW) & $\begin{array}{l}\text { DC-AC efficiency, 90\%; AC-DC efficiency, } \\
85 \% \text {; capacity (rectifier/inverter), } 100 \%\end{array}$ \\
\hline
\end{tabular}


Table 15 Additional input specification for biogas generator fuel

\begin{tabular}{lll}
\hline Parameter & Specification & Remarks/reference \\
\hline Biomass quantity (tons/day) & 136.58 & Summation of all the considered dry matters below \\
Biomass cost $(\$ /$ tons $)$ & 0 & Wastes minimization for environmental benefits \\
Biomass aggregate carbon $\mathrm{C}(\%)$ & 26.34 & Calculated based on the share of each waste in total \\
Biogas to biomass ratio on aggregate $(\mathrm{kg} / \mathrm{kg})$ & 0.27 & $\begin{array}{l}\text { Calculated based on the share of biogas potential of } \\
\text { each waste in the total }\end{array}$ \\
Low heating value of biogas $(\mathrm{MJ} / \mathrm{kg})$ & 20 & Selected from a range $/[29]$ \\
Biogas' density $\left(\mathrm{kg} / \mathrm{m}^{3}\right)$ & 1.2 & Selected from a range $/[29]$ \\
Biogas' $\mathrm{CO}_{2}$ emission factor $(\mathrm{g} / \mathrm{kWh}$ elec $)$ & 3.12 & Homer Pro conventional setting
\end{tabular}

Biomass considered: cow-dung: (65.75 tons/day, C $22.5 \%, 0.24 \mathrm{~kg}$ biogas/kg DM), goat-dung: (47.12 tons/day, C 29.5\%, $0.2 \mathrm{~kg}$ biogas/kg DM), sheep-dung: (15.97 tons/day, C:31.4\%, $0.3 \mathrm{~kg}$ biogas $/ \mathrm{kg} \mathrm{DM})$, chicken-dung: (7.32 tons/day, C 32.4\%, $0.34 \mathrm{~kg}$ biogas $/ \mathrm{kg} \mathrm{DM})$, horse-dung: (0.42 tons/day, C $41.5 \%, 0.36 \mathrm{~kg}$ biogas $/ \mathrm{kg}$ DM) [reference to Table 1]

Table 16 Energy efficiency (EE) assessment input specifications

\begin{tabular}{ll}
\hline Parameters & Specification \\
\hline Calculated total costs of considered appliances in baseline case & $\$ 3180$ \\
Calculated total costs of appliances as substitute for the EE measure & $\$ 15,420$ \\
Calculated capital cost increment on implementing the EE measure & $\$ 12,240$ \\
Calculated load power reduction on implementing the EE in summer & $51 \%$ \\
Calculated load power reduction on implementing the EE in winter & $40 \%$ \\
Calculated power reduction based on the seasons' energy weights & $44 \%$ \\
Energy efficiency (EE) multiplier input & $100-44 \%=56 \%$ \\
Energy efficiency (EE) lifetime input & 25 years \\
\hline
\end{tabular}


The Proposed Grid-connected System

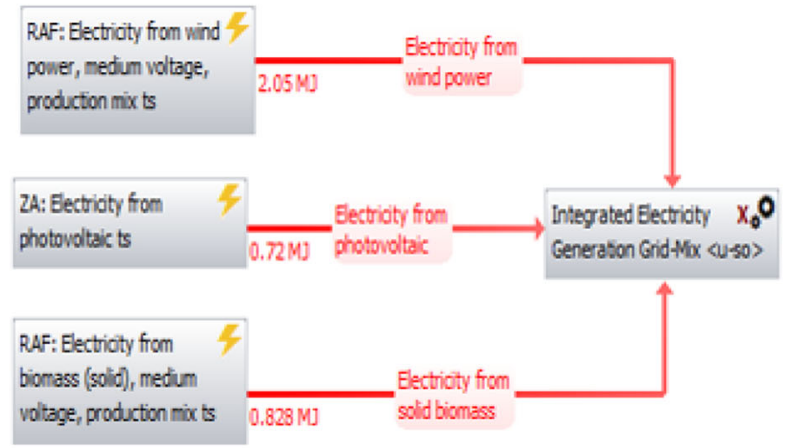

The Proposed Grid-connected System with EE Measures

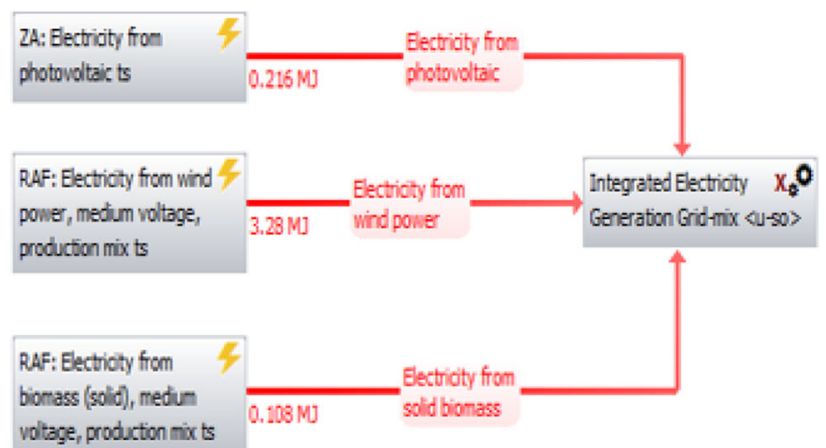

The Grid-only Power Supply (Conventional System)

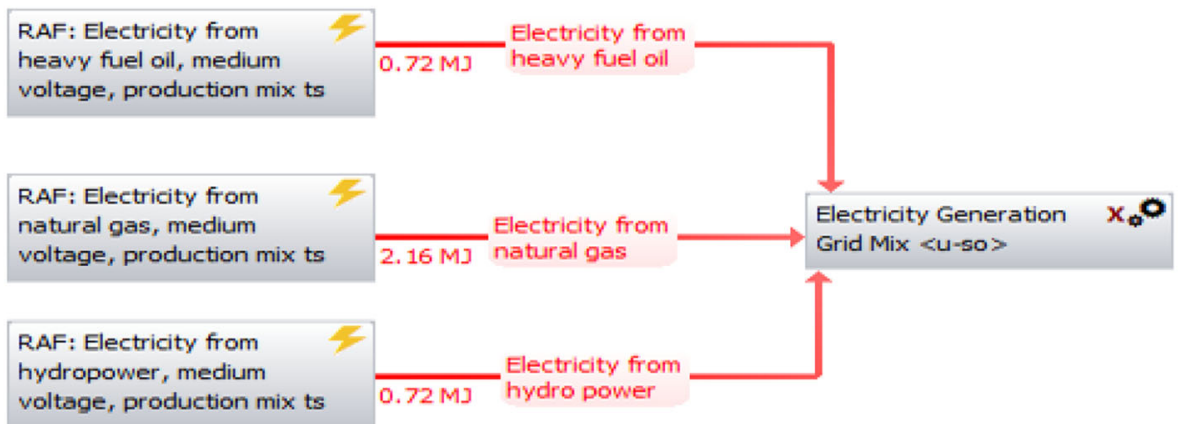

Fig. 17 The applied model for the supplementary life cycle emissions assessment in GaBi. Grid-only conventional power mix data ratio sourced from [45]. [Basis, $1 \mathrm{kWh}$ functional unit/equivalent to the $3.6 \mathrm{MJ}$ total reference flows in each case]

\section{Abbreviations}

AP: Acidification potential; CRF: Capital recovery factor; DPBP: Discounted payback period; EE: Energy efficiency; GaBi: Ganzleitlichen Bilanz; GWP: Global warming potential; HOMER: Hybrid Optimization Model for Electric Renewables; IRR: Internal rate of return; LCOE: Levelized cost of energy; NPC: Net present cost; ODP: Ozone-layer depletion potential; PBP: Payback period; ROI: Return on investment

\section{Acknowledgements}

This study was carried out under the project "Water and Energy Security in Africa (WESA-ITT)," with special recognitions to the support of the supervisors and other members of the project.

\section{Authors' contributions}

Conceptualization, development, and analyses: I.A.J; overall writing: I.A.J; additional analysis suggestions: R.B; review, corrections, and overall supervision: R.B and A.Z. The author(s) read and approved the final manuscript.

\section{Funding}

Full funding has been secured from the German Federal Ministry of Education and Research (BMBF) via its Project Management Agency DLR.

\section{Availability of data and materials}

Data are available upon request.

\section{Ethics approval and consent to participate}

Not applicable

\section{Consent for publication}

Not applicable

\section{Competing interests}

The authors declare no competing interest.

\section{Author details}

${ }^{1}$ Mechanical Engineering Department, Faculty of Technology, University of Tlemcen, B.P. 119/Pôle Chetouane, 13000 Tlemcen, Algeria. ${ }^{2}$ Pan African University Institute of Water and Energy Sciences - PAUWES, c/o University of Tlemcen, B.P. 119/Pôle Chetouane, 13000 Tlemcen, Algeria. ${ }^{3}$ Institute for Technology and Resources Management in the Tropics and Subtropics, TH Köln - University of Applied Sciences, Betzdorfer Strasse 2, 50679 Cologne, Germany.

Received: 17 September 2019 Accepted: 9 July 2020

Published online: 28 August 2020

\section{References}

1. US Department of Energy (DOE) (2001) Hybrid renewable energy systems. In: Renewable Energy Workshop, Colorado

2. Negi S, Mathew L (2014) Hybrid renewable energy system: a review. Int J Electron Electrical Eng:8

3. Rakesh S, Mohanty D, Maharana T, Pareek N (2016) Designing and study standalone hybrid energy system: for technical institutes. Int J Inf Res Rev 03:6

4. E. Kelechi. Rural electrification infrastructure development in Nigeria using on-grid and off-grid sources. n.pub. n.d.

5. Christoper A, Frank D (2017) Combination of PV and central receiver CSP plants for base load power generation in South Africa. J Solar Energy:10 Available at Science Direct

6. Ileberi G, Adikankwu H, Timi E, Adenekan O (2016) Grid-integration of renewable technology: a techno-economic assessment. Am J Mech Eng 4

7. Numbi B, Malinga S (2017) Optimal energy costs and economic analyses of a residential grid-interactive solar PV system: case of eThekwini municipality in South Africa. J Appl Energy:18 Available at Science Direct 
8. Nadjema O, Nacer T, Hamidat A, Salhi H (2016) Optimal hybrid PV / wind energy system sizing: application of cuckoo search algorithm for Algerian dairy farms. J Renewable Sustainable Energy Rev:14 Available at Science Direct

9. Mohammed B, Rachid E, Elhammoumi K, Khanfara M (2016) Optimal sizing of grid-connected PV-wind system: case study of agricultural farm, Morocco. J Theor Appl Inf Technol 82:11

10. Amos M, Sparks D, Samantha K, Moorlach M (2015) Optimization of PV-wind hybrid system under limited water resources. J Renewable Sustainable Energy Rev: Available at Science Direct:8

11. Silinga C, Gauche P, Rudman J, Cebecauer T (2014) Energy procedia: the South African REIPPP two-tier CSP tariff, implications for a proposed hybrid CSP peaking system: Available at Science Direct. In: International Conference on Concentrating Solar Power and Chemical Energy Systems, Solar PACES, 2014

12. Kazem HA, Khatib T (2013) Techno-economical assessment of grid connected photovoltaic power systems productivity in Sohar, Oman. Sustainable Energy Technol Assessments 3:5

13. Gonzalez A, Riba J-R, Rius A (2015) Optimal sizing of a hybrid gridconnected photovoltaic-wind-biomass power system. Sustainability 7(09): 20

14. Salahi S, Adabi F, Mozafari SB (2016) Design and simulation of a hybrid micro-grid for Bishesh village. Int J Renewable Energy Res 6(1):13

15. Dali M, Belhadj J, Roboam X (2010) Hybrid solarewind system with battery storage operating in grid-connected and standalone mode: control and energy management experimental investigation. Energy 35:09

16. Nurunnabi M, Roy N (2015) Grid-connected hybrid power system design using HOMER. In: International Conferences on Advances in Electrical Engineering, Dhaka, Bangladesh

17. Global Energy Statistical Year Book (2017) Nigerian electricity production [Online]. Available: https://yearbook.enerdata.net/electricity/world-electricityproduction-statistics.html. Accessed Oct 2017.

18. Worldometers Population (2017) Countries in the world by population (2017). [Online]. Available: http://www.worldometers.info/world-population/ population-by-country/. Accessed Mar 2017.

19. Stephen IO, Egwuonwu G, Osazuwa I (2012) Delineation of all-seasonrecharged ground water reservoir from two valleys, Zaria, Nigeria. J Environ Hydrol 20:9

20. Population.city (2015) Zaria population. [Online]. Available: http://population. city/nigeria/zaria/. Accessed Nov 2017

21. Samuel Y (2013) Assessment of water quality of hand-gug wells in Zaria LGA of Kaduna state, Nigeria. Int J Eng Sci 2(11):04

22. Global Biodiversity Information Facility (GBIF) (2015) DIVA-GIS. [Online] Available: https://www.gbif.org/tool/181420/diva-gis. Accessed 2020

23. National Aeronautics Space Administration (NASA) (2017) Surface meteorology and solar energy. [Online]. Available: https://eosweb.larc.nasa. gov/sse/RETScreen/. Accessed Oct 2017.

24. Food and Agricultural Organization (FAO) (2017) Crops data. [Online]. Available: http://www.fao.org/faostat/en/\#data.

25. Simonya K, Fasina O (2013) Biomass resources and bioenergy potentials in Nigeria. Afr J Agric Res 8:15

26. United Nations Environmental Program (UNEP) (2013) Technologies for converting waste agricultural biomass to energy. United Nations Environmental Program (UNEP), Osaka

27. Paul D, Nicolae F, Matei F (2014) Main factors affecting biogas production an overview. Rom Biotechnol Lett J 19:14

28. Moral R, Moreno J, Perez M (2004) Characterisation of the organic matter pool in manures. J Bioresour Technolo: Available at Science Direct:6

29. D. Ludington (n.d.) Biogas heating value calculations. n.pub.

30. Muyiwa A, Martin AC, Samuel PS (2014) Analysis of hybrid energy systems for application in southern Ghana. J Energy Conversion Manage: Available at Science Direct:12

31. Muyiwa A, Quansah D, Agelin CM, Paul SS (2017) Multipurpose renewable energy resources based hybrid energy system for remote community in Northern Ghana. J Sustainable Energy Technol Assess:10

32. Kusakana K, Vermark HJ (2014) Cost and performance evaluation of hydrokinetic-diesel Hybrid System. In: Energy Procedia: The 6th International Conference on Applied Energy - ICAE2014 Available at Science Direct

33. Taher M, Ghodhbane N, Sassi BN (2016) Assessment viability for hybrid energy system (PV/wind/diesel) with storage in the northernmost city in
Africa: Bizerte, Tunisia. J Renewable Sustainable Energy Rev: Available at Science Direct:14

34. Fraunhofer Institute for Solar Energy (FISE) (2012) Levelized cost of electricity, renewable energies. Fraunhofer ISE, Freiburg

35. Nigerian Electricity Regulatory Commission (NERC) (2015) Amended multi year tariff order (Myto) - 2.1 for the period April 1st, 2015 to December, 2018. NERC, Abuja

36. Nigerian Electricity Regulatory Commission (NERC) (n.d) Nigerian energy supply industry (NESI). [Online]. Available: https://www.nercng.org/. [Accessed Dec 2018].

37. Akpojedge FO, Onogbotsere ME, Mormah EC, Onogbotsere PE (2016) A comprehensive review of Nigeria electric power transmission issues and rural electrification challenges. Intern J Eng Trend Technpol 31:9

38. International Energy Agency (IEA) (2018) Policies and measures for renewable energy: Nigeria statistical timeline. [Online]. Available: http:// www.iea.org. [Accessed 2018].

39. GreenStarNetwork (2017) Low carbon virtual private clouds. [Online]. [Accessed Oct 2017].

40. Sadeghi M, Gholizadeh B, Gilanipoor J, Khaliliaqdham N (2012) Economic analysis of using of wind energy, case study of Baladeh city of north Iran. Int J Agric Crop Sci:8

41. Sara S, Rita P, Malmquist A, Pina A (2015) Feasibility study of using a biogas engine as backup in a decentralized hybrid (PV/wind/battery) power generation system: case study of Kenya. J Energy: Available at Science Direct:12

42. Cat-Electric Power (2011) Gas generator set: AG biogas. n.Pub.

43. Common Wealth of Australia (2008) Emissions estimation manual technique for combustion engines. National Population Inventory.

44. Davis U (2012) Revised air quality and greenhouse gas emissions calculations

45. The Shift Project (n.d) Nigerian electricity production. [Online]. Available: http://www.tsp-dataportal.org/. Accessed April 2017.

\section{Publisher's Note}

Springer Nature remains neutral with regard to jurisdictional claims in published maps and institutional affiliations.
Ready to submit your research? Choose BMC and benefit from:

- fast, convenient online submission

- thorough peer review by experienced researchers in your field

- rapid publication on acceptance

- support for research data, including large and complex data types

- gold Open Access which fosters wider collaboration and increased citations

- maximum visibility for your research: over $100 \mathrm{M}$ website views per year

At BMC, research is always in progress.

Learn more biomedcentral.com/submissions 